UDC 94(477.83)«1940»

DOI: 10.24919/2519-058x.7.130646

Vasyl ILNYTSKYI,

Ph D hab. (History), Associate Professor, Head of Department of Ukraine's History of Ivan Franko Drohobych State Pedagogical University

(Ukraine,Drohobych) vilnickiy@gmail.com

\title{
SPOTTING AND LIQUIDATION OF UKRAINIAN, POLISH AND JEWISH ORGANIZATIONS IN DROHOBYCH BY SOVIET REPRESSIVE UNITS (1940) ${ }^{1}$
}

In the articles an excerpt from an intelligence-operative agency case of the struggle of Soviet repressive-punitive administration against Ukrainian, Polish, and Jewish both illegal and legal organisations has been analysed. The published document provides the chance to disclose the features of establishment of the Soviet administration in Drohobych and to trace the extent of the local repressive policy towards the political, public, cultural, and religious organisations. The document is kept in the Security service of Ukraine's branch state archive, more particularly, in Fund 71 (The Acts of transfer of archival documentary materials of UCSS (Ukrainian Committee of State Security) in Lviv region into archive $(1939-1991)$.

Key words: Drohobych, an intelligence-operative agency case, Ukrainian, Polish, and Jewish legal and illegal organizations, repressive-punitive bodies.

Василь ІЛЬНИЦЬКИЙ, orcid.org/0000-0002-4969-052X доктор історичних наук, дочент завідувач кафедри історії України

Дрогобииького державного педагогічного університету імені Івана Франка (Украӥна, Дрогобич) vilnickiy@gmail.com

\section{ВИЯВЛЕННЯ ТА ЛІКВІДАЦІЯ РАДЯНСЬКИМИ РЕПРЕСИВНО-КАРАЛЬНИМИ ОРГАНАМИ УКРАЇНСЬКИХ, ПОЛЬСЬКИХ ТА ЄВРЕЙСЬКИХ ОРГАНІЗАЦІЙ У м. ДРОГОБИЧ (1940р.)}

У статті проаналізовано витяг із агентурно-оперативної справи про боротьбу радянської репресивно-каральної адміністрачії із українськими, польськими, єврейськими нелегальними і легальними організаціями. Публікований документ дає змогу розкрити особливості становлення радянської адміністрації у м. Дрогобич, простежуються масштаби репресивної політики щзодо політичних, громадських, культурних, релігійних організачій. Документ зберігається у Галузевому державному архіві Служби безпеки України, зокрема у фонді 71 (Акти передачі архівних документальних матеріалів УКДБ у Львівській області в архів (1939 - 1991 рр.).

Ключові слова: Дрогобич, агентурно-оперативна справа, украӥнські, польські, єврейські легальні та нелегальні організації, репресивно-каральні органи.

1 Публікація містить результати досліджень, проведених у рамках виконання наукового проекту «Українсько-польсько-єврейські взаємини у Східній Галичині (перша половина XX ст.): історичний досвід, уроки для сучасності», що фінансується за рахунок коштів загального фонду державного бюджету. ID:95861 29.08.2017 (176-1) 
Problem statement. The problem of formation and establishment of Soviet administration in the West Ukrainian lands belongs to actual scientific problems, which have drawn and will draw the attention of researchers. During dozens of years this problem have been elucidated one-sidedly, its documentary base has been under the signature stamp «top secret». The acquisition of independence by Ukraine has opened possibilities for an objective and complex illumination of this question. In particular, this process has become more active with opening of access and declassification of archive funds.

An active struggle against all political, public, educational, and cultural organizations (whether Ukrainian, Polish, or Jewish) became an important compound of the activity of the Soviet administration in West Ukrainian lands. For that, the repressive-punitive system used a complex of forms and methods which had been approved in East Ukraine. The illumination of this question will show not only the process of struggle, its scale and means thus used, but will also help to study the history, structure, personal strength and basic lines of activity of Ukrainian, Polish and Jewish organizations of the West Ukrainian region.

The analysis of sources and recent researches. Separate aspects of the problem of formation and establishment of the Soviet administration have been considered, first of all, in the generalizing works of Ivan Bilas, Yuriy Kyrychuk, Anatoliy Rusnachenko, and Ivan Patryliak (Bilas, 1994; Kyrychuk, 2003; Rusnachenko, 2002; Patryliak, 2012). The collective, summarizing monograph of the working group on the research of the activity of OUN and UPA, which contains sections about the Sovietization of the West Ukrainian areas, is also important for the illumination of this problem (OUN and UPA, 2005). More in details the issue of the opposition of the Soviet repressive-punitive system against the Ukrainian and Polish underground is considered in the works of Volodymyr Serhiychuk, Yuriy Shapoval, Stepan Makarchuk (Makarchuk, 2004; Serhiychuk, 2005; Shapoval, 2001). The issue of functioning of the Polish underground, its relation with the Ukrainian liberation movement, and its opposition to the repressive-punitive system was most fully studied by Ihor Iliushyn (Iliushyn, 2003; Iliushyn, 2001; Iliushyn, 2009). Separate aspects of the policy of Sovietization of Western Ukraine were studied by M. Lytvyn, O. Lutsky, K. Naumenko, K. Kondratyuk, S. Kondratyuk, B. Yarosh, V. Nikolskyi (Lytvyn, Lutsky, Naumenko, 1999; Lutsky, 2001; Kondratyuk, 2000; Yarosh, 1999; Nikolskyi, 2003). However, the declassification of a chai of archival funds allows the researches to essentially replenish the available information on the scale, form and methods of Sovietization of the western region of Ukraine (1939 - 1941).

The article's purpose is to add available information on the struggle of Soviet repressive-punitive organs against the Ukrainian, Polish, and Jewish organizations in Drohobych (1940).

Statement of the basic material. The published document includes an excerpt of a rather voluminous (178 pages.) case of the intelligence-operative agency development of all legal (though, after the arrival of the Soviet administration, all organisations were forbidden and became illegal) and illegal Ukrainian, Polish, and Jewish organizations of Drohobych region. Most probably, the case was opened in 1940. The case № 9 is kept in Fund 71 (The Acts of transfer of archival documentary materials of UCSS in Lviv region into archive (19391991) of the Security Service of Ukraine's branch state archive. The workers of the UNCIA (Ukrainian National Committee of Internal Affairs) of Drohobych region are the authors and compilers of these documents. In the whole collection very detailed biographical date concerning nearly two thousand persons, who were accused in accordance with the two hundred forty secret-service cases, are presented. In this article only a part of that case is published, including the information on almost 400 persons, who were participants in nearly 50 legal and illegal organizations. 
In general, the presented in the document information can be divided in three parts: number and name of the secret-service case, the list of persons who pass on it, and a short description of the purpose and the objective of an organisation.

The result of the collected, during a short time, information on all illegal and legal organizations are really amazing. The specificity and completeness of the received data deserves a separate notification. From the document the researchers learn about the widely branched out and structured networks of the legal and illegal organizations of the Ukrainians, Poles, and Jews. What can be assuredly asserted, is that in the result of the use of a whole complex of actions in 1940 the Soviet power bodies possessed a huge scope of agency-operative information, which they actively realised by means of arresting and repressing everyone, who made or, potentially, could make a resistance to the establishment of the Soviet administration in the West Ukrainian lands. A special efficiency and work productivity of the secret service agency should be accentuated hereby.

Conclusions. What should be primarily mentioned, is the fact that the published document is an important source for a complex study of the question of the formation and establishment of the Soviet administration in Drohobych. It is quite certain, that this material can essentially help the further scientific, because it provides the valuable information, like the surnames and names of the organisations' members, without which any search in the archive of the Ukraine's State Service Administration in Lviv region is impossible.

The document is for the first time entered into the scientific circulation in the source language. In the publication the lexicon, author's and editorial features of the text of the source is as much as possible preserved. The personal and geographical names are presented without any changes. Only the most evident grammatical flaws have been subjected to corresponding corrections. The document is accompanied with the legend constituting the document's place of preservation (the archive's name, the number of the fund, description, case, pages).

\section{The document}

СПО УНКВД:

231 АГДЕЛО № 135 «Радисты».

1730. СЛАТВИНСКИЙ Тадей Владиславович, 1901 г. рожд., урож. и жив. г. Дрогобыч, поляк, б/п, работал слесарем мастерской Облуправления связи, при польских властях работал нач. электросети г. Дрогобыч, имел связи с членами партии «эндеков».

1731. ПАШНЕВ Василий Ильич, 1912 г. рожд., урож. с. Хохлова, Сажневского p-на, Курской обл., русский, из кулаков, прожив. г. Дрогобыч, военнослужащий, мл. воентехник, имел родственников на территории Германии, поддерживал связь с женами быв. офицеров польармии, эмигрировавших в Германию.

Разрабатывались как резко настроенные лица против соввласти.

СПИСОК

СОВЕРШЕНО СЕКРЕТНО

$$
\begin{gathered}
\text { Лиц, разрабатываемых по действующим агентурным делам } \\
\text { УНКВД Дрогобычской области } \\
\text { ПО СПО: }
\end{gathered}
$$

Агдело № 107 «Недобитые»

1. ТАНЕНБАУМ Леопольд Якубович, 1924 г. рожд., урож. и. жит. г. Борислав, еврей, сын бывш. офицера польской армии, учащийся техникума. 
2. КУРЕК Эдуард Брониславович, 1918 г. рожд., прожив. г. Борислав, учащийся техникума.

3. РЕГАВТ Адольф Осипович, 1922 г. рожд., прожив. г. Борислав, еврей, учащийся техникума.

4. ВЖАСКА Марьян Губертович, 1924 г. рожд., прожив. г. Борислав, поляк, учащийся техникума.

5. ЗИНГЕР Антон Соломонович, 1923 г. рожд., прожив. г. Борислав, учащийся техникума.

Разрабатывались как контрреволюционная группа, стремящаяся бежать за границу, где принять участие с иностранными войсками в борьбе против соввласти.

Агдело № 51 «Радисты»

6. ЧАСКОВСКИЙ Ян-Казимир Брониславович, 1906 г. рожд., урож. и жит. г. Дрогобыч, ул. Столярская, поляк, б/п, работал пом. машиниста на заводе «Нафта».

7. Энгель Здислав Станиславович, 1919 г. рожд., урож. и жит. г. Дрогобыч, поляк б/п, работал бойцом горпожкоманды. по подозрению.

Разрабатывались в проведении вражеской деятельности, направленной против соввласти, поддерживали связь из зарубежом, посредством нелегальной радиостанции.

Агдело № 153 «Воинственные скворцы»

8. ПАШУЛЬКА Адам Юльянович, 1918 г. рожд., урож. и жит. г. Дрогобыч, ул. Листопада № 71, поляк, б/п.

9. ФАЛЯНДЫС Бронислав Петрович, 1921 г. рожд., урож. и жит. г. Дрогобыч, ул. Войтовская гора № 148-б, поляк, б/п.

10. СКШИПЕЦ Казимир Францевич, 1923 г. рожд., урож и жит. г. Дрогобыч, ул. Поперечная № 1 кв. 2, поляк, б/п.

11. СТУПНИЦКИЙ Збигнев Мечиславович, 1917 г. рожд., урож. г. Романов, прожив. г. Дрогобыч, ул. Листопада № 27, поляк, б/п, являлся членом организации «гарцежи».

Разрабатывались как контрреволюционная молодежная организация «ПОВ», проводящая антисоветскою деятельность. Эта организация имела оружие и намеривалась использовать ее против соввласти.

Агдело № 28 «Надежда»

12. БОГАЧ Юльян Данилович, 1922 г. рожд., урож. и жит. г. Борислав, Дрогобыческая уд. № 33-б, поляк, б/п, без опр. занятий.

13. ОНАЦИШИН Ян Маркусович, 1920 г. рожд., урож. и жит. г. Борислав, ул. Дрогобыческая № 33-б, поляк, б/п, без опр. занятий.

14. СКИБОВА Владислава Хоронимна, 1908 г., рожд., урож. г. Дрогобыч, прожив. г. Борислав, Дрогобыческая ул. № 33-б, полька, б/п, домохозяйка, являлась комендантом организации «стрелец».

15. ЛОБОЗА Янина Яновна, - Ивановна, 1914 г. рожд., урож. с. Сельково, прожив. г. Борислав, ул. Щепановского № 23, полька, б/п, без опр. занятий.

Разрабатывались в проведении к-р повстанческой деятельности.

Агдело № 45 - «Бандиты»

16. ОСИНСКИЙ Юзеф, 1905 г. рожд., прожив. г. Дрогобыч, ул. Стрийская 40, поляк, б/п, без опр. занятий, б. офицер польармии. 
17. ПЕТРИН Казимир, 1913 г. рожд., поляк, б/п, без опр. занятий, прожив. г. Дрогобыч, ул. Болонная.

18. МОЛОТОК /МУЛОТЕК/, 1902 г. рожд., поляк, б/п, без опр. занятий, бывш. майор польской армии.

Разрабатывались как участники подпольной польской к-р повстанческой организации, ставившей своей целью свержение соввласти в Западных областях Украины.

Агдело № 281 - «Недовольные»

19. СТОЩАК-ФИШЕР Гелена Антоновна, 1907 г. рожд., урож. и. жит. гор. Дрогобыч ул. Пушкина № 92, полька, б/п, домохозяйка.

20. ФИШЕР Янина Антоновна, 1911 г., урож. и жит. г. Дрогобыч, полька, б/п, без опр. занятий.

21. ЭМЕРЛЕ-ФИШЕР Стефания Антоновна, 1914 г. рожд., урож. и жит. г. Дрогобыч ул. Пушкина № 92, полька, б/п, домохозяйка.

Разрабатывались по подозрению в проведении антисоветской деятельности, поддерживали тесную связь с сестрой, высланной вглубь СССР.

Агдело № 97 - «Легионеры»

22. МЛЫНАЖ Клименс-Болеслав Иосифович, 1889 г. рожд., урож. и. жит. г. Дрогобыч ул. Блонная № 14, поляк, работал педагогом в школе, бывш. активный участник «ПОВ», являлся заместителем председ. уездного комитета «ПОВ».

В связи с прекращением агдела подлежал переводу на д.ф.

23. ЛОРЕНЦ Станислав Лойзевич, 1893 г. рожд., урож. г. Станислав, прожив. г. Дрогобыч ул. Горького № 42, поляк, в прошлом являлся активным участником и членом уездного комитета «ПОВ», имел свою кустарную электромастерскую.

В связи с прекращением агдела подлежал переводу на д.ф.

24. УРБАНОВИЧ Иван Бартоломеевич, 1891 г. рожд., урож. и. жит. г. Дрогобыч поляк, бывш. активний участник и член уездного комитета организации «ПОВ», работал на заводе «Салина».

В связи с прекращением агдела подлежал переводу на д.ф.

25. РИБНЕР Казимир Иванович, 1903 г. рожд., урож. и. жит. г. Дрогобыч, Горького № 42, поляк, бывш. активний участник и член уездного комитета организации «ПОВ», работал бухгалтером Облздравотдела.

В связи с прекращением агдела подлежал переводу на д.ф.

26. ВЖАСЕК Эмель Петрович, 1901 г. рожд., урож. г. Самбор, прожив. г. Дрогобыч, ул. Снежная № 6, поляк, бывш. судья польского суда, до прихода Красной Армии являлся председателем уездного комитета по организации «ПОВ».

Нелегально бежал за кордон.

27. КАПУСТЯК Антон Михайлович 1892 г. рожд., урож. г. Львов, прожив. в г. Дрогобыч, ул. Юра № 39, бывш. активный участник и член уездного комитета организации «ПОВ», поляк, нелегально бежал за кордон.

28. БОБРАЙ Томаш Йосифович 1896 г. рожд., урож. и жит. г. Дрогобыч, ул. Малая № 5, поляк, бывш. активный участник и член уездного комитета организации «ПОВ», нелегально бежал за кордон.

29. КОБРИН Зигмунд-Виктор Иванович-Янович, 1893 г. рожд., урож. г. Дрогобыч, поляк, бывш. активный участник организации «ПОВ». 
Разрабатывалисьпоподозрению в проведении организованной контрреволюционной нац. деятельности против соввласти.

Агдело № 119 «Заговорщики»

30. КОБРИН Дзюнек-Владислав Янович, 1905 г. рожд., урож. и жит. г. Дрогобыч, ул. Шевека № 6, поляк, б/п, кустарь сапожник, бывш. офицер польской армии.

31. ДОМБРОВСКИЙ Андрей Севастьянович, 1904 г. рожд., урож. и жит. г. Дрогобыч, ул. Франко № 9, поляк, б/п, без опр. занятий.

Разрабатывались по подозрению в проведении антисоветской деятельности.

Агдело № 93 - «Легионисты»

32. ВАЖНЫЙ Тадеуш Карлович, 1912 г. рожд., урож. г. Самбор, прожив. г. Дрогобыч, ул. Стрийская № 233, поляк, б/п.

33. КЕЦОНЬ Владислав Степанович, 1921 г. рожд., прожив. г. Дрогобыч, ул. Фабричная № 1, поляк, б/п.

34. КОТОВИЧ Валерьян Юзефович, 1918 г. рожд., урож. и жит. г. Дрогобыч, ул. Польна № 57, поляк, б/п, без опр. занятий.

35. ЯБЛОНСКИЙ Владислав-Иосиф Мартынович, 1901 г. рожд., урож. г. Добромиль, прож. г. Дрогобыч, ул. Собесского 4, поляк, б/п.

36. ГУДЕЧЕК Францишек Иванович, 1876 г. рожд., урож. г. Львов, прожив. г. Дрогобыч, поляк, б/п.

37. ГУДЕЧЕК Стефания Григорьевна, 1900 г. рожд., урож. м. Рогатин, Станиславской обл., прожив. г. Дрогобыч, ул. Блонна № 9.

38. ГЛУШКО Зигмунд, прожив. г. Дрогобыч, ул. Стрийская № 249, поляк, б/п.

Разрабатывались, как польские националисты, в 1940 г. являлись организаторами по вербовке в Венгрию польских офицеров и националистов, для вступления там в польские легионы, для нападения на СССР.

Агдело № 54 - «Мыслители»

39. ВОЙТОВИЧ Эмиль Юзефович, 1894 г. рождения, прожив. г. Дрогобыч, ул. Грунвальдская № 60 .

40. ЦЫБУЛЬСКИЙ Игнат Антонович, 1894 г. рожд., урож. и жит. г. Дрогобыч, ул. Церковная № 2, работал на заводе бывш. «Польми».

41. БАЛЕЦКИЙ Адам Варфоломеевич, 1897 г. рождения, поляк, прожив. г. Дрогобыч.

42. ТОПОЛЬ Томаш Войцехович, 1894 г. рожд., поляк, работал на заводе «Польми», прожив. г. Дрогобыч.

В связи с прекращением агдела подлежал переводу на д.ф.

43. ДОЧЬ Тадеуш Антонович, 1893 г. рожд., прожив. г. Дрогобыч, поляк,

В связи с прекращением агдела, подлежал переводу на д.ф.

44. АДАМСКИЙ Эдмунд Юзефович, 1901 г. рожд., прожив. г. Дрогобыч, поляк.

В связи с прекращением агдела подлежал переводу на д.ф.

45. ЮШАВЕЦКИЙ Михаил Николаевич, 1895 г. рожд., урож. и жит. г. Дрогобыч, ул. Горишня Брама № 8, поляк, б/п, работал слесарем в транспортной конторе «Укрнефтедобыча», в прошлом член фашистской организации «333» и др. нац. организаций. В начале 1940 г. нелегально пришел из Германии на совсторону.

В связи с прекращением агдела подлежал переводу на д.ф. 
Разрабатывались по подозрению в проведении антисоветской деятельности распространению провокационных слухов против СССР.

Агдело № 203 - «Гнездо»

46. КАВЕЦКИЙ Кароль Шимонович, 1896 г. рожд., урож. и жит. г. Дрогобыч, ул. Садовая № 12, поляк, б/п, работал на дому сапожником.

47. САРВАТКО Станислав Севастьянович, 1880 г. рожд., урож. и жит. г. Дрогобыч, ул. Горишня Брама № 55, поляк, б/п, кустарь.

48. ВЗОРЕК Станислав Михайлович, 1885г. рожд., урож. г. Львов, прожив. г. Дрогобыч, ул. Беднарского № 7, поляк, б/п, работал в артели «Металлист».

49. ВАЛЕК Иосиф Францевич, 1905 г. рожд., урож. г. Лабенць Пинчовского р-на, прожив. г. Дрогобыч, ул. Садовая № 6-а, поляк, парикмахер.

50. ЯНУШЕВИЧ Кароль Казимирович, 1892 г. рожд., урож. г. Дрогобыч, прожив. г. Дрогобыч, ул. Шевченко № 9, б/п, сторож школы.

51. ЯНУШЕВИЧ Франц Каролевич, 1920 г. рожд., урож. и жит. г. Дрогобыч, ул. Шевченко № 9, поляк, б/п.

52. КЛЕРМАН Пинкус Маркусович, 1922 г. рожд., урож. и жит. г. Дрогобыч, ул. Снежная № 1, еврей, б/п, учащийся.

53. ЛОБАСЬ Владимир Михайлович, 1894 г. рожд., урож. и жит. г. Дрогобыч, ул. Бориславская № 50, поляк, б/п.

Разрабатывались, как участники польской нац. организации, проводили к-р деятельность.

Агдело № 352 - «Настойчивые»

54. ГНАТИК Станислав Иванович, 1908 г. рожд., урож. г. Львов, прожив. г. Дрогобыч, Бичная Горького № 36, поляк, б/п, работал монтером АТС, состоял членом организации «стрельцов».

55. СЕНИВ Фроил Николаевна, 1909 г. рожд., урож. г. Тернополь, прожив. г. Дрогобыч, Стрийская № 78, полька, б/п, работала секретарем АТС.

56. СЕРЕМАК Войцех Иванович, 1897 г. рожд., урож. с. Бохня Краковского воеводства, прожив. г. Дрогобыч, ул. Комсомольская № 17, поляк, б/п, работал монтером АТС, в прошлом состоял в польском легионе, принимал участие в боях против Красной Армии в 1920 г.

57. ЖИГУЛЕВСКИЙ Адольф Якубович, 1909 г. рожд., урож. и жит. г. Дрогобыч, поляк, б/п, работал монтером АТС, состоял членом спортивного военного общества «Юнак» и организации стрельцов.

Разрабатывались как контрреволюционная группа, состоящая из бывших членов антисов. организаций стрельцов и «герцежа», враждебно настроенных против соввласти.

\section{3. Агдело № 56 «Мечтатели»}

58. ЖИГУЛЕВСКИЙ Иосиф Тимофеевич, 1908 г.рожд., урож. Пидбуж, прож. г. Дрогобыч, поляк, бывш. капрал польской армии, состоял членом ППС и участником по организации стрельцов, работал в горпожкоманде.

59. ГЛЕНЬ Антон Михайлович, 1899 г. рожд., урож. м. Санок, Германия, прожив. г. Дрогобыч, работал шофером пожкоманды, поляк, быв. активный член ППС.

60. АПОЛИНСКИЙ Бронислав Иванович, 1899 г. рожд., урож. с. Губичи, прожив. г. Дрогобыч, поляк, работал в пожкоманде, добровольно служил в петлюровской армии. 
61. ФУРЗИН Михаил Владиславович, 1909 г. рожд., урож. и жит. г. Дрогобыч, поляк, работал шофером пожкоманды, бывш. капрал польской армии.

62. КИСИЛЬ Кастер Михайлович, 1907 г. рожд., урож. с. Дубляны, Самборского p-на, прожив. г. Дрогобыч, поляк, работал шофером пожкоманды, бывш. капрал польской армии.

Разрабатывались по подозрению в проведении антисоветской деятельности и распространении антисоветских слухов.

14. Агдело № 50 - «Коршуны»

63. ГОСТИЛЬ Хилярий Мартвянович, прожив. г. Борислав, работал педагогом коммерческой школы, поляк, б/п, бывш. капитан польской армии.

64. МОТЫКИВИЧНА Анна Валентиновна, 1900 г. рожд., прожив. г. Борислав, полька, б/п, без опр. занятий.

65. ДМИТРЕНКО Евгений Григорьевич, 1915 г. рожд., прожив. г. Борислав, поляк, б/п, бывш. польский офицер. польармии.

66. МИХАЛЬСКИЙ Степан Владимирович, 1905 г. рожд., прожив. г. Борислав, поляк, б/п, бывш. руководитель организации скаутов.

67. МАРУСЯК Франц Иванович, 1899 г. рожд., прожив. г. Дрогобыч, поляк, б/п.

68. НОЙСЕРЕК Бронислав Якубович, 1886 г. рожд., прожив. г. Борислав, поляк, б/п, бывший активный пеовяк.

69. РАЧКОВСКИЙ Станислав Янович, 1898 г. рожд., прожив. г. Борислав, поляк, б/п, бывш. член ППС.

70. РАЧКОВСКИЙ Тадеуш Станиславович, 1920 г. рожд., прожив. г. Борислав, поляк, б/п.

71. ТВАРДЫЙ Збигнев Станиславович, 1920 г. рожд., прожив. г. Дрогобыч, поляк, б/п.

72. СУРОВЯК Александр Янович, 1907 г. рожд., прожив. г. Борислав, поляк, б/п, член ППС.

73. ТАЙНОБРАМСКАЯ Анна, 1920 г. рожд., прожив. г. Борислав, полька, б/п.

74. ЯРОШЕВСКИЙ Георгий Казимирович, 1923 г. рожд., прожив. г. Борислав, поляк, б/п.

75. ШОППА Адольф Францишкович, 1907 г. рожд., прожив. г. Борислав, бывш. член союза резервистов.

76. ЩАНЕК Стефан Евгеньевич, 1911 г. рожд., прожив. г. Дрогобыч, поляк, б/п.

77. ЧЕХОРОВСКИЙ Эрвин Станиславович, 1897 г. рожд., прожив. г. Дрогобыч, поляк, б/п, б. подофицер-резервист, состоял в организации «Млада польска».

Разрабатывались по подозрению в проведении организованной польской нац. антисоветской деятельности, подготавливали вооруженное восстание против сов.власти.

[...]5. Агдело № 229 «Ходаки»

78. ЯНИЦКАЯ Мария Степановна, 1882 г. рожд., уроженка и жит. г. Дрогобыч, ул. Жупна № 32, полька, б/п, иждивенка.

79. ЯНИЦКИЙ Болеслав Стефанович, 1918 г. рожд., урож. и жит. г. Дрогобыч, ул. Франко № 122, поляк, б/п, работал завхозом Ушосдора НКВД.

80. ЯНИЦКИЙ Збышек Стефанович, урож. г. Дрогобыч, бежал в Венгрию.

81. ЯНИЦКИЙ Бобось Стефанович, бежал в Венгрию, поляк, б/п. 
Разрабатывались, как подозрительные по шпионажу в пользу одного из иностранных государств.

16. Агдело № 239 - «Жолтоблакитные»

82. БАРАНИК Григорий Николаевич, 1894 г. рожд., урож. г. Угнив, Рава-Руссского p-на, прожив. г. Дрогобыч, ул. Стрийская № 17, украинец, б/п, работал товароведом в облпотресоюзе, ранее проживал в Италии.

В связи с прекращением агдела подлежал переводу на списочный учет с заведением на него учетного дела.

83. БАРАНЕЦКАЯ Ярослава Николаевна, 1916 г. рожд., урож. и жит.ница Воля-Якубова, украинка, б/п, работала в музыкальном институте учительницей в г. Дрогобыче, дочь попа.

В связи с прекращением агдела, подлежал переводу на списочный учет с заведением на него учетного дела.

84. ФРУДЗЕН Иван Григорьевич, 1875 г. рожд., урож. и жит. г. Дрогобыч, ул. Гоголя №19, украинец, б/п, до 1939 г. работал в Дрогобычском магистрате в качестве официала.

В связи с прекращением агдела подлежал переводу на списочный учет с заведением на него учетного дела.

Разрабатывались как связанные с польской диверсионной группой, скрывающейся в Карпатах на территории Венгрии, а также по подозрению в переправе лиц за кордон.

[...]7. Агдело № 315 - «Паразиты»

85. МАНЖОС Александр Андрианович, 1910 г. рожд., урож. м. Вороновцы, Винницкой обл., прожив. г. Дрогобыч, ул. Польная №14, укр., член ВЛКСМ, работал директором конторы «Главкинопрокат».

86. ХЦЮК Филиция Ивановна, 1914 г. рожд., урож. и жит. г. Дрогобыч, ул. Фабричная, № I-a, укр., б/п, без опр. занят, жена быв. офицера.

87. КОВАЛЫК Янина Францишковна, 1910 г. рожд., урож. Живец, прожив. г. Дрогобыч, ул. Фабричная, № I-a, полька, б/п, без опр. занятий, муж бывш. офицер во время польско-германской войны бежал в Венгрию.

88. ВИННИЧУК Адам Иванович, 1919 г. рожд., крож. г. Городок, прожив. г. Дрогобыч, ул. Фабричная, № I-a, б/п, работал в охране завода № 2, бывш. Галиция.

Разрабатывались как участники шпионской группы лиц, приходящих из Венгрии и передачи последним материалов шпионского характера.

18. Агдело № 26 «Мстители»

89. БАРАННИК Северин Никитович, 1889 г. рожд., урож. с. Угнив, Рава-Русского p-на, прожив. г. Дрогобыч, укр., б/п, игумен украинской церкви, состоял членом УНДО и «Просвіти».

90. СИНКРИВСКИЙ Иван Семенович, 1896 г. рождения, ур. г. Тернополь, прожив. г. Дрогобыч, украинец, б/п, священник укр. церкви, из кулаков, в прошлом член УНДО и «Просвіти».

91. КРИНИЦКИЙ Роман Емельянович, 1881 г. рожд., урож. с. Плангино, Германия, прожив. г. Дрогобыч, украинец, б/п, работал священником украинской церкви, сын служителя религиозного культа, бывш. член УНДО и «Просвіти».

92. МОДРИЦКИЙ Иосиф Стефанович, 1865 г. рожд., урож. и жит. Дрогобыч, украинец, б/п, священник украинской церкви, ранее примыкал к партии УНДО, состоял членом «Просвіти». 
93. ТЕСОВСКИЙ Иван Степанович, 1866 г. рожд., урож. с. Рудаковцы, бывш. Мостицкого района, прожив. г. Дрогобыч, украинец, б/п, священник украинской церкви, примыкал к организации «УНДО, являлся членом «Просвіти», поддерживал связь с братом, находящимся в Чехословакии.

94. ЖУПАНСКИЙ Павел Павлович, 1885 г. рожд., урож. с. Пилипин, бывш. Коломинского повита, прожив. г. Дрогобыч, укр., б/п, священник украинской церкви, являлся членом организации «Просвіта».

95. ГВОЗДИВСКИЙ Петр Васильевич, 1912 г. рожд., урож. с. Артасьев, бывш. Жовсковского повита, прожив. г. Дрогобыч, укр., без опр. занятий, служит. религиозного культа, из кулаков, ранее примыкал к партии УНДО.

96. ГРУБЫЙ Михаил Александрович, 1896 г. рожд., урож. с. Агитна, бывш. Жовсковского повита, прожив. г. Дрогобыч, укр., б/п, служит. религиозного культа, сын священника, состоял в организации «Просвіта».

97. БАГУНВасилий Емельянович, 1903 г. рожд., урож. с. Цеблево, бывш. Сокальского повита, укр., б/п, служит. религиозного культа, из кулаков, ранее примыкал к партии УНДО, бывш. Член «Просвіти».

98. НИЩИЙ Эдуард Петрович, 1879 г. рожд., урож. с. Борщавицы, Львовской обл., прожив. г. Дрогобыч, укр., б/п, священник украинской церкви, из середняков, бывш. член УНДО и «Просвіти».

99. СЛОНСКИЙ Юлиан, 1889 г. рожд., прожив. с. Модричи, Дрогобычской обл., укр., б/п, симпатизировал партии УНДО.

100. ЖУК Виктор, 1888 г. рождения, прожив. с. Михайлевичи, Дрогобычск. р-на, укр., б/п, принадлежал к партии УНДО.

101. МАТЫНОВИЧ Омелья, 1875 г. рожд., прожив. с. Тустановичи, Дрогобычск. p-на, укр., б/п, ранее принадлежал к партии УНДО.

102. ИВАНУСИВ Николай, 1873 г. рожд., прожив. с. Вацевичи, Дрогобичск. р-на, укр., б/п, священник украинской церкви, в прошлом член УНДО.

103. ПЛЕШКЕВИЧ Юлиан, 1895 г. рожд., прожив. г. Самбор, в прошлом член партии УНДО.

104. КОНЦИЛОВСКИЙ Йосафат, 1876 г. рожд., прожив. г. Перемышль, укр., б/п, епископ г. Перемышль.

105. КРУЦЬКО Андрей, 1887 г. рожд., прожив. с. Добровляны, Меденичского р-на, укр., б/п, примыкал к парти УНДО.

106. ЯЦЕВ Нестор, 1895 г. рожд., ур. б/п, священник гор. Борислав, бывш. член УНДО.

Разрабатывались как церковная группа бывш. членов УНДО, проводившая контрревоционную работу под руководством игумена Баранника против мероприятий соввласти.

19. Агдело № 402 «Саранча»

107. ШЕВЧУК Владимир Семенович, 1886 г., рожд., урож. с. Березка, Дрогобычск. обл., прожив. г. Стрый, ул. Ланы № 19, укр., б/п.

108. ГОЛОВКЕВИЧ Василий Михайлович, 1920 г. рожд., урож. и жит. с. Болеховцы, Дрогобычского р-на, укр., б/п, работал в своем сельском хозяйстве.

109. КОБИЛЬНИК Степан Михайлович, 1909 г. рожд., урож. и жит. г. Дрогобыч, укр., б/п, работал на заводе № 1, бывш. активный член организации «ОУН». 
110. ГУБИЦКИЙ Илья Васильевич, 1900 г. рожд., урож. и жит. с. Болеховцы, Дрогобычского р-на, укр., б/п, занимался сельским хозяйством.

Подозревались в причастности к антисоветской оуновской организации, в прошлом активные украинские националисты.

20. Агдело № 369 - «Коновальцы»

111. ПОРЦИНА Дмитрий Андреевич, 1913 г. рожд., урож. и жит. с. Монастырец, Журавновского р-на, укр., б/п, работал в сельском хозяйстве.

112. КНЫШ Юрий, 1918 г. рожд., урож. и жит. с. Монастырец, Журавновского р-на, укр., б/п, работа в сельском хозяйстве.

113. МАРЧУК Семен, урож. и жит. с. Монастырец, Журавновского р-на, укр., б/п, работал нач. участка, райконторы связи, польским судом был осужден за активное участие в организации «ОУН».

114. КОСТЕЛЬНЫЙ Николай, 1917 г. рожд., урож. и жит. с. Монастырец, Журавновского р-на, укр., б/п, работал в своем сельском хозяйстве.

115. ШЕВЧУК Данил, 1913 г. рожд., урож. и жит. с. Буянов Журавновского р-на, укр., б/п, работал в своем сельском хозяйстве.

116. ЗУБ Иван Васильевич, урож. и жит. с. Корчевка, Журавновского р-на, укр., б/п, работал в своем сельском хозяйстве, сын кулака.

Разрабатывались, как активная группа, организации украинских националистов «ОУН», ставящей себе целю свержение существующего строя.

\section{1. Агдело №84 - «Римляне»}

117.БАНАССтаниславШимонович, 1888 г. рожд., урож. сел. Сельница,Перемышльского р-на, прожив. г. Дрогобыч, поляк, б/п, игумен римо-католического костела.

118. СОПАЛЬСКИЙ Францишек Францишкевич, 1877 г. рожд., урож. с. Кольчицы, быв. Краковского воеводства, прожив. г. Дрогобыч, Войтова Гора, №46, поляк, б/п, ксендз римо-католического костела.

119. ПЕЛЬЧАР Михаил Казимирович, 1890 г. рожд. с. Кростинко-Вижня, прожив. в г. Дрогобыч, ул. Польна № 12, поляк, б/п, ксендз римо-католического костела.

120. БАРЦ Иосиф Войцехович, 1912 г. рожд., урож. с. Забара, Тешевского повита, прожив. г. Дрогобыч-Польна Т-20, поляк, б/, ксендз римо-католического костела.

121. ТОЧЕК Валентин Матвеевич, 1871 г. рожд., урож. с. Нозджец, Бжешевского повита, прожив. г. Дрогобыч, ул. Жупна № 7-а, поляк, б/п, ксендз римо-католического костела.

122. ГЛЯЗАР Иосиф Иванович, 1984 г. рожд., урож. с. Кростинко-Вижня, прожив. г. Дрогобыч, поляк, б/п, ксендз римо-католического костела.

123. ГАЗДА Казимир-Иван Войтехович, 1915 г. рожд., урож. с. Соколов, б. Кольбушевского повита, прожив г. Дрогобыч, ул. Вольна № 20, поляк, б/п, ксендз римо-католического костела, сын фабриканта.

124. КИТКО Степан Матвеевич, 1904 г. рожд., уроженец с. Нова-Гора, Кшановского повита, прожив. г. Дрогобыч, ул. Польна № 20, поляк, б/п, монах римо-католического костела.

125. ТОМИЦЕК Августин Каролевич, 1914 г. рожд., урож. с. Гашовичи, б. Рудницкого повита, прожив. г. Дрогобыч, ул. Польна № 20, поляк, б/п, монах, органист польского костела. 
Группа духовенства римо-католического костела проводила активно к-р работу, распространяла антисоветские провокационные слухи.

22. Агдело № 359 - «Гранадеры»

126. НИМИЛОВИЧ Мария Теодоровна, 1918 г. рожд., урож. с. Медики, прожив. г. Дрогобыч, ул. Чкалова № 48, украинка, б/п, без опр. занятий, дочь священника.

127. НИМИЛОВИЧ Дмитрий Николаевич, 1885 г. рожд., урож. и жит. г. Дрогобыч, ул.Стрийская 137, укр., б/п, работал в своем сельском хозяйстве.

128. НИМИЛОВИЧ Емельян Теофилович, 1908 г. рожд., урож. и жит. г. Дрогобыч, ул. Стрийская № 61, укр., б/п, работал в своем сельском хозяйстве, брат его арестован как видный украинский националист.

129. НИМИЛОВИЧ Ульян Теофилович, 1890 г. рожд., урож. и жит. г. Дрогобыч, ул. Стрийская 61, укр., б/п., работал в своем сельском хозяйстве, брат его арестован как активный член «ОУН».

130. НИМИЛОВИЧ Юльян Нестерович, 1911 г. рожд., урож. и жит. г. Дрогобыч, ул. Стрийская № 75, укр., б/п, работал слесарем на заводе № 1.

131. КОГУТ Григорий Михайлович, 1898 г. рожд., урож. и жит. г. Дрогобыч, ул. Стрийская № 37-б, укр., б/п, работал бухгалтером Облпотребсоюза, в прошлом активный украинский националист, член ораганизации «ОУН», за что арестовывался польской полицией.

132. ЛЕВИТАН Игнатий Абрамович, 1909 г. рожд., урож. и жит. г. Дрогобыч, еврей, б/п, зубной техник поликлиники,

133. КРАНН Филипп Самойлович, 1900 г. рожд., урож. г. Львов, прожив. гор. Дрогобыч, ул. Ленина № 21, еврея, б/п, работал зубным техником поликлиники.

Разрабатывались по подозрению в участии в украинской антисоветской оуновской организации.

\section{3. Агдело № 351 «Неугомонные»}

134. ГРИНАДА Юзефа Войцеховна, 1910 г. рожд., урож. г. Пидгайцы, Тернопольской обл., прожив. г. Дрогобыч, ул. Войтовская Гора, № 34, полька, б/п, являлась связисткой и переправщицей людей за границу,

135. ЦЫМБРИКЕВИЧ Юлия Ивановна, 1904 г. рожд., урож. и жит.ница г. Дрогобыч, ул. Войтовская Гора, № 16, полька, б/п, являлась переправщицей людей на сторону Венгрии.

136. БЛАЖЕВА Агнета Ивановна, 1901 г. рожд., урож. и жит. г. Дрогобыч, ул. Войтовская Гора № 16, полька, б/п, являлась переправщицей людей на сторону Венгрии.

Разрабатывались по подозрению в переправе людей на территорию Венгрии.

24. Агдело № 109, «Специалисты»

137. ОБЕРЛЕНДЕР Густав Давыдович, 1905 г. рожд., урож. и жит. г. Борислав, еврей, б/п, работал техником в Облмельтресте, в прошлом имел собственный магазин.

138. КАМЕРМАН Генрих Михайлович, 1905 г. рожд., урож. и жит. г. Борислав, еврей, б/п, работал инженером Облмильтреста, бывш. владелец нефтеразработки.

139. КЛЯРЕВ Александр Аронович, 1910 г. рожд., урож. и жит. г. Дрогобыч, еврей, член партии сионистов, работал экономистом Облмельтресте, бывш. адвокат.

140. КУПФЕРБЕРГ Эдвард Моисеевич, 1914 г. рожд., урож. и жит. г. Дрогобыч, ул. Мицкевича № 31, еврей, б/п, работал техником в Облмельтресте, бывш. владелец мебельного магазина, состоял в организации «звязку». 
141. РАПП Самуил Якубович, 1910 г. рожд. урож. и жит. г. Дрогобыч, еврей, б/п, работал инженером в Облмельтресте, бывш. владелец магазина.

Разрабатывались как группа антисоветски настроенных лиц, занимавшихся систематической антисоветской агитацией.

\section{5. Агдело № 77, «Гашомерцы»}

142. БРЕНЕР Натан Якубович, 1920 г. рожд., урож. и жит. г. Дрогобыч, ул. Яна № 25, еврей, студент технической школы являлся активным участником еврейскофашистской организации сионистов-ревизионистов.

143. ШТИФЕЛЬ Шарлота Ароновна, 1920 г. рожд., урож. г. Дрогобыч, ул. Польная № 59, еврейка, студентка технической школы, являлась активной сионистской и руководителем молодежной организации «Гашомер-Гацоир».

144. ОРЕНШТАЙН Отыля Гершовна, 1923 г. родж., урож. г. Дрогобыч, еврейка, студентка технической школы, прож. г. Дрогобыч, ул. Собесского № 24, состояла членом бундовской молодежной организации «Цукунфат», антисоветски настроена.

145. КИТАЙГОРОДСКАЯ Етка Рафаиловна, 1920 г. рожд., урож. г. Дрогобыч, прожив. г. Дрогобыч, ул. Райха № 22, еврейка, студентка технической колы, состояла в сионистской организации «Гашомер» и бундовской молодежной организации «Цукунфат».

Разрабатывались по окраске «сионисты» как антисоветская группа, а/с настроенных лиц.

\section{6. Агдело № 235 - «Изменники»}

146. РАУХ Соломон Абрамович, 1906 г. рожд., урож. и жит. г. Дрогобыч, ул. Франко № 3, еврей, б/п, работал в художественной мастерской, быв. член КПЗУ, исключен за троцкизм.

147. РАУХ Мендель Абрамович, 1910 г. рожд. и жит. г. Дрогобыч, ул. Франко № 3, еврей, работал зав. комбинатом индпошива, в 1939 г. приехал из Парижа, быв. чл. КПЗУ.

148. ГЛИК Абрам Айзикович, 1908 г. рожд. и жит. г. Дрогобыч, еврей, б/п, работал бухгалтером типографии «Большевистска правда».

149. ГЛИК-ГРИНВАЛЬД Элена Лейзеровна, 1907 г. рожд. и жит. г. Дрогобыч, ул. Горького № 27, еврейка, б/п, работала в школе по обучению малограмотных.

150. ГРИНВАЛЬД Рахиль Лазаревич, 1910 г. рожд. и жит. г. Дрогобыч, ул. Мицкевича № 40, еврей, б/п, работал портным на дому.

151. ШРАЕР Файвель Пинкасович, 1909 г. рожд., урож. и жит. г. Дрогобыч, ул. Беднарская ул. № 11б, еврей, б/п, работал главным инженером жилуправления.

Разрабатывались по окраске «троцкисты», группировавшиеся и проводившие антисоветскую деятельность.

27. Агдело № 90 - «Клерикалы»

152. АВИГДОР Яков Абрамович, 1895 г. рожд., урож. м. Тира-Вавольска, Плесковского р-на, прожив. г. Дрогобыч, еврей, сын торговца, руководитель религиозной организаций «Агуда» и «Магзика-Годат», является окружным равином.

153. ЛАНДЕМАН Абрам Хаскалевич, 1863г. рожд., урож. м. Буск, б. Каменского повита, Львовской обл., еврей, б. торговец, равин, имеет свой молильный дом.

154. НУСЕМБУН Вольф Давидович, 1877 г. рожд., урож. г. Стрий, прожив. 
г. Дрогобыч, еврей, быв. торговец, чл. «Кагала» и руководитель религиозной организации «Агуда», равин гор. Дрогобыч.

155. АЛЬСТЕР Герш Мойшевич, 1891 г. рожд., урож. г. Львов, прож. г. Дрогобыч, еврей, б. торговец, руководитель организации «Агуда», являлся служителем религиозного культа в молильном доме.

156. ПАНЦЕР Лейб Йосифович, урож. и жит. гор. Дрогобыч, еврей, в прошлом крупный торговец и владелец кирпичного завода и фабрики свечей, руководитель религиозной организации «Агуда», являлся служителем религиозного культа.

157. ЛЯБЕН Шулен Сендерович, 1892 г. рожд., урож. г. Борислав, прожив. г. Дрогобыч, еврей, бывш. торговец, последнее время являлся подравином.

158. БИЛЯК Берль Шмелькович, 1890 г. рожд., урож. Шежец, того же повита, Германия, прожив. г. Дрогобыч, еврей, в прошлом крупный торговец, руководитель религиозной организации «Магзика годат», являлся служителем религиозного культа.

159. ЛИБЕР Копель Озиашевич, 1883 г. рожд., урож. с. Лимна, б. Турковского повита, прожив. г. Дрогобыч, еврей, в прошлом торговец, активный религиозник и руководитель организации «Агуда».

160. ФЕНСТЕР Сруль, урож. Г. Стрий, прожив. г. Дрогобыч, чл. «Кагала», руководитель религиозной организации «Макзикагодас», являлся равином.

Группа еврейского клерикального духовенства, разрабатывалась как проводившая активную контрреволюционную деятельность.

28. Агдело №68 «Галерчики»

161. ТОРГОВСКИЙ Тадеуш Иванович, 1886 г. рожд., урож. г. Самбор, прож. г. Дрогобыч, ул. Грунвальская, № 24, поляк, работал врачем на дому, являлся активным членом «Союза галерчиков».

162. СВИДОРСКИЙ Йосиф Войцехович, 1890 г. рожд., ур. с. Зборецький, Старый Константинов, прож. г. Дрогобыч, ул. Тихая, № 5, поляк, работал шорником на заводе №1 б. Польми, являлся членом «Союза галерчиков».

163. БРУСИК Петр Янович, 1900 г. рожд., ур. г. Развадов, прож. г. Дрогобыч, ул. Грунвальская, № 75, поляк, являлся активным членом «Союза галерчиков», в последнее время находился на нелегальном положении.

164. ПЕНЦАК Йосиф Янович, 1893 г. рожд., урож, г. Львов, прож. г. Дрогобыч, ул. Стрийская, № 121, поляк, чернорабочий завода № 1, являлся активным членом «Союза галерчиков», последнее время находился на нелегальном положении.

Разрабатывались по окраске «польская к-р», как члены военно-фашистского союза галерчиков, созданного генералом Галлером.

29. Агдело №382 «Обреченные»

165. ХОМЧИНСКИЙ Ярослав Иванович, 1912 г. рожд., урож. с. Ступница, Самборского р-на, ул. Снежная, № 3, укр, б/п, студент пединститута.

166. БАРАНЯК Йосиф Михайлович, 1921 г. рожд., урож. с. Подбуж, Дорогобычской обл., прож. г. Дрогобыч, ул. Снежная, № 43, укр., б/п, студент пединститута.

167. ФРАНКО Иван Григорьевич, 1919 г. рожд., урож. с. Нагуевичи, Подбужского p-на, прож. г. Днепропетровск, военная часть № 340, укр., б/п, служил в Красной Армии.

168. Чайковский Мирослав Владимирович, 1920 г. рожд., урож. с. Микакло, Самборского р-на, ул. Снежная, № 43, укр. б/п, студент пединститута. 
169. РЫМЕЦ Владимир Михайлович, 1922 г. рожд., урож. с. Тершив, Стрелковского p-на, прож. г. Дрогобыч, ул. Снежная, № 43, укр., б/п, студент пединститута.

Разрабатывались по подозрению в проведении к-р нац. деятельности. Этой группой студентов руководил до ухода в армию ФРАНКО Иван.

30. Агдело №127 «Гимназисты»

170. БАТОГ Марьян Теофилович, 1921 г. рождения, урож. г. Борислав, прожив. г. Дрогобыч, Стрийская 103, поляк, учащийся польской гимназии, сын урядника, состоял членом организации «ПОВ».

171. ШИМЛЛЕР Мечеслав-Осип Мнович, 1918 г. рожд., урож. и жит. г. Дрогобыч, ул. Юра № 49, поляк, учащийся польской гимназии, состоял членом организации «ОВ».

172. КОЛЕНДОВСКИЙ Юрик /Ежик/ Марьянович, 1923 г. рожд. урож. г. Борислав, прож. г. Дрогобыч, ул. Бартоломея № 21, поляк, учащийся польской гимназии, сын урядника, являлся членом организации «ПОВ».

173. КОПАЧИНСКИЙ Здислав Влацлавович, 1923 г. рожд., урож. и. жит. г. Дрогобыч, ул. Крашевского № 2, поляк, сын учителя, состоял членом организации «ПОВ».

174. ВАЙКРЕБ Йосиф, 1922 г. рожд., урож. и жит. г. Дрогобыч, ул. Гарцарского № 18, еврей, учащийся польской гимназии, сын рабочего, состоял членом организации «ОВ».

175. РОЛЛЕВИЧ Збигнев Янович, 1923 г. рожд., урож. и жит. г. Дрогобыч, ул. Вийтовская гора № 94, поляк, учащийся польской гимназии, сын урядника, состоял членом организации «ПОВ».

176. ЖУЛЬКЕВИЧ Лешек Станиславович, 1920 г. рожд., урож. г. Краковец, прож. г. Дрогобыч, ул. Польма, № 17, поляк, учащийся польской гимназии, состоял членом организации «ПОВ».

177. ГЕКСЕЛЬ Ян-Николай Юзефович, 1923 г. рожд., урож. и жит. г. Дрогобыч, ул. Собесского № 26, поляк, учащийся польской гимназии, сын купца, отец арестован НКВД, являлся участником организации «ПОВ», последнее время находился на нелегальном положении.

178. ЛИНДЕР Тадеуш-Здислав Генрихович, 1924 г. рожд., урож. и жит. г. Дрогобыч, поляк, учащийся польской гимназии, являлся участником организации «ПОВ».

179. СВАРОВСКАЯ Ванда Юзефановы, 1923 г. рожд., урож. и жит. г. Дрогобыч, ул. Жупна № 42, полька, учащаяся польской гимназии, являлась учасником организации «ПОВ».

180. СВАРОВСКАЯ Гелена Казимировы, 1922 г. рожд., урож. с. Нове Мисто, под Древендою, прож. г. Дрогобыч, ул. Жупна № 42, учащаяся польской гимназии, являлась участником организации «ПОВ».

181. КОБРИН Янина Зигмундовы, 1922 г. рожд., урож. и жит. г. Дрогобыч, ул. Завалля № 2, полька, учащаяся польской гимназии, являлась участником организации «ПОВ».

182. ВЗОРЕК Эдуард Станиславович, 1922 г. рожд., урож. и жит. г. Дрогобыч, ул. Беднарского № 7, поляк, учащийся польской гимназии, являлся участником организации «ПОВ».

183. ТЕВЛЕНКА Варвара-Ирина Владимировна, 1921 г. рожд., урож. и жит. г. Дрогобыч, ул. Листопада № 15, полька, б/п, учащаяся школы № 12. 
Разрабатывались по подозрению в проведении антисоветской, польской нац. деятельности, направленной против мероприятий соввласти.

32.Агдело № 126 «Медики»

184. ЧИЖЕВСКИЙ Казимир Брониславович, 1898 г. рожд., урож. г. Львов, прожив. г. Дрогобыч, ул. Грунвальская № 67, поляк, б/п, врач-хирург, бывш. капитан резерва польской армии, в прошлом член партии «ОЗН».

185. МИХАЛЬЧИК Владислав Константинович, 1911 г. рожд., урож. г. Борислав, прож. г. Дрогобыч, поляк, б/п, работал врачем больницы №1.

186. ДУБИЦКИЙ Изидор Васильевич, 1905 г. рожд., урож. г. Тернополь, прожив. г. Дрогобыч, укр., б/п, работал врачем больницы №1.

187. ЧИЖЕВСКАЯ Ивона Осиповна, 1900 г. рожд., урож. г. Львов, прожив. Грунвальская ул., № 67, г. Дрогобыч, полька, б/п, работала врачем больницы № 1 .

Группа антисоветских настроенных лиц, под руководством активного члена «ОЗН» ЧИЖЕВСКОГО проводит антисоветскую работу.

32. Агдело № 264 «Курсисты»

188. КОЛОМЕЕЦ Лев, 1915 г. рожд., урож. г. Перемышля, прожив. г. Дрогобыч, студент пединститута.

189. КОМАРОВСКИЙ Святослав, 1921 г. рожд., урож. с. Нижанковичи, Перемышльского р-на, прожив. г. Дрогобыч, студент пединститута.

190. ЛЕЩИШИН Василий, 1920 г. рожд., ур. с. Поляны, Дрогобычского р-на, студент пединститута.

191. ХИМЯК Иван, 1920 г. рожд., урож. с. Новосилькидит, прож. г. Дрогобыч, студент пединститута.

192. КУПИЧ Виктор Николаевич, 1919 г. рожд., ур. г. Самбор, прож. г. Дрогобыч, ул. Грунвальдская № 12, студент пединститута.

193. ВЕЛИТЯК Павел, 1920 г. рожд., урож. с. Грушатичи, Перемышльского р-на, прож. г. Дрогобыч, студент пединститута.

Разрабатывались по подозрению в проведении активной антисоветской деятельности, распространяя а/с агитацию

33. Агдело №129 «Дружинники»

194. ЯКУБОВСКАЯ Любов Михайловна, 1921 г. рожд., урож. и жит. г. Дрогобыч, ул. Снежная № 33, укр., б/п, ученица школы им. Франко.

195. НЕМИЛОВИЧ Мирон Теодорович, 1922 г. рожд., урож, с. Тинев, прож. с. Унятычи, Дрогобычского р-на, укр., б/п, учащийся школы.

195. ЗУЛЯК Владимир Александрович, 1920 г. рожд., урож. с. Ставок, прож. г. Дрогобыч, ул. Бориславская № 1, укр., б/п, учащийся школы.

196. НЕМИЛОВИЧ Елена Теодоровна, 1924 г. рожд., урож. г. Самбор, прожив. с. Унятычи, Дрогобычского р-на, укр., б/п, учащийся школы, дочь священника.

197. СТЕЦКОВ Степан Иванович, 1925 г. рожд., урож. с. Грушев, Медыничского p-на, прожив. там же, укр., б/п, учащийся школы.

198. КАЛЕНСОВСКИЙ Лев Эпполитович, 1923 г. рожд., урож. и жит. с. Трускавец Дрогобычского р-на, укр., б/п, учащийся школы.

Разрабатывались как члены «Марийской дружины», проводящие антисоветскую работу. 
34. Агдело № - «Семейка»

199. СВАРОВСКАЯ Геленада Йосифовна, 1901 г. рожд., урож. и жит. г. Дрогобыч, ул. Жупна №42, полька, б/п, домозяйка, родственники проживают в Германии.

200. ЦЫБУЛЬСКАЯ Пелагея Ванцентовна, 1862 г. рожд., урож. Нью-Йорка, США, прож. г. Дрогобыч, ул. Жупна № 42, зять арестован, дочь выслана, два сына находятся в Германии.

201. СВАРОВСКИЙ Казимир Йосифович, 1885 г. рожд. урож. села Яворив, Львовской обл., прож. г. Дрогобыч, ул. Жупна № 42, поляк, б/п, работал в Стройотделе, в прошлом работал секретарем польского суда.

202. СВАРОВСКАЯ Олена Казимировна, 1922 г. рожд., урож. и жит. г. Дрогобыч, ул. Жупна № 42, полька, б/п, занималась в заочном институте.

Разрабатывались по подозрению в проведении антисоветской деятельности, поддерживали письменную связь с лицами, высланными вглубь СССР.

35. Агдело №321 «Саламандра»

203. ДУБИЦКАЯ Мария Брониславовна, 1921 г. рожд., урож. и жит. г. Дрогобыч, ул. Мицкевича № 42, полька, б/п, без определенных занятий, являлась членом костельной организации.

204. ДЮГ Янина Мациновна, 1922 г. рожд., урож. г. Дрогобыч, прож. с. Ставище, Дрогобычского р-на, полька, б/п, без определенных занятий, быв. член костельной организации.

205. ЗГУТ Максимильян Станиславович, 1917 г. рожд., урож. г. Дрогобыч, прож. с. Болеховцы, Дрогобычского р-на, поляк, б/п, без определенных занятий.

206. КАВЕЦКАЯ Чеслава Брониславовна, 1921 г. рожд., урож. г. Дрогобыч, прож. там же, ул. Жупна № 24, быв. член костельной организации.

207. КУХАРСКАЯ Янина Ивановна, 1992 г. рожд., урож. м. Черхава, Самборского р-на, прож. г. Дрогобыч, ул. Слиппа, № 2, полька, б/п, без определенных занятий, быв. член костельной организации, отец арестован органами НКВД.

208. СТРИЧЕК Михалина Михайловна, 1919 г. рожд., урож. и жит. г. Дрогобыч, ул. Мицкевича, № 20, полька, б/п, работала на медбазе.

209. СТРИЧЕК Ядвига Михайловна, 1920 г. рожд., урож. и жит. г. Дрогобыч, ул. Мицкевича, №20, полька, б/п, без определенных занятий, быв. член костельной организации.

210. ФУРОВИЧ Гелена Эдвардовна, 1920 г. рожд., урож. и г. Дрогобыч, ул. Камелярская № 3, полька, б/п, без опредиленных занятий, быв. член костельной организации.

211. МОНГОЛЬД Мария Франковна, 1914 г. рожд., урож. и жит. г. Дрогобыч, ул. Поперечная, № 3, полька, б/п, без определенных занятий, быв. член костельной организации.

212. МОНГОЛЬД Здислава Михайловна, 1922 г. рожд., урож. и жит. г. Дрогобыч, ул. Горького, № 18, полька, б/п, без определенных занятий, быв. член костельной организации.

Разрабатывались как группа тайной организации польского Красного креста, организованная членом «ПОВ», проводила а/с работу. 
36. Агдело № 162 «Радиолюбители»

213. БАРАНОВСКИЙ Тадей Болеславович, 1884 г. рожд., урож. с. Больша, Херсонской губ, прожив. г. Дрогобыч, ул. Бартоломея, № 14, поляк, б/п, работал врачем поликлиники, в прошлом активный член партии «ЭНД», быв. капитан резерва.

214. НОВАКОВСКИЙ Владислав Иванович, 1892 г. рожд., урож. г. Ярослав, Германия, прож. г. Дрогобыч, поляк, б/п, врач поликлиники.

215. ВИТЕР Бронислав Владиславович, 1904 г. рожд., урож. г. Тернополь, прож. г.Дрогобыч, ул. Горького, № 12, б/п, врач поликлиники, быв. член партии, «ЭНД.».

Разрабатывалась как группа антисоветки настроенных, проводящая к-р разговоры.

37. Агдело № 287 «Чорные орлы»

216. ДЕРЕНГОВСКИЙ Антоний Казимирович, 1925 г. рожд., урож. села Збойска, (Германия), прожив. г. Дрогобыч, ул. Революции, № 7, поляк, б/п, учащийся школы, отец арестован.

217. МАТИСЯКЕВИЧ Леонард Станиславович, 1924 г. рожд., урож. и жит. г. Дрогобыч, ул. Стрийская № 159, поляк, б/п, учащийся школы.

218. СТОНЧАК Станислав Вильгельмович, 1923 г. рожд., урож. и жит. г. Дрогобыч, ул. Вокзальная № 3, поляк, б/п, работал на ж.д.

Молодежная к-р повстанческая организация, разрабатывалась по подозрению в проведении a/c работы.

\section{8. Агдело № 247 «Интуристы»}

219. СТОРХ Симха, 1892 г. рожд. урож. с. Гнилье, Сколевского р-на, прожив. г. Дрогобыч, еврей, б/п, кустарь-портной, занимался переправой беженцев в Чехию.

220. СТОРХ Моисей Симхович, 1915 г. рожд., урож. с. Гнилье, Скольевского р-на, прожив. г. Дрогобыч, ул. Чацкого № 15, еврей, б/п, без опр. занятий.

221. СТОРХ Шлейм Симхович, 1914 г. рожд., урож. с. Гнилье, Сколевского р-на, прожив. г. Дрогобыч, ул. Чацкого № 15, еврей, б/п, без опр. занятий.

222. ДАВЕРМАН Ицек, 1907 г. рожд., урож, и жит. г. Дрогобыч, еврей, б/п, без опр. занятий, польским судом был осужден за воровство к тюремному заключению.

223. ШТАЙФ Идаль, 1917 г. рожд., урож. и жит. г. Дрогобыч, ул. Крыжа, еврей, б/п, без опр. занятий.

Разрабатывались, как группа, занимавшаяся переправой лиц за кордон и контрабандной деятельностью.

39. Агдело № 243 «Связисты»

224. ВИЛИНСКИЙ Карл Карлович, 1906 г. рожд., урож. г. Бережаны, Тарнопольской обл., прожив. г. Дрогобыч, ул. Листопада, поляк, б/п, не работал, бывш. чл. «ОЗН», сын кадрового капитана польской армии.

225. ЛИНДЕРОВА Матильда Францевна, 1902 г. рожд., урож. г. Львов, прожив. г. Дрогобыч, ул. Чкалова № 18, полька, б/п, не работала, состояла членом организации «O3H».

226. БУЛЬФАН Альбин Владимирович, 1895 г. рожд., урож, и жит. г. Дрогобыч, ул. Листопада № 6, поляк, б/п, работал начальником почтового отделения ж.д. почты, в прошлом член организации «ПОВ» и «ОЗН», польский националист. 
227. БУЛЬФАН Владимир Владимирович, 1897 г. рожд., урож. и жит. г. Дрогобыч, ул. Листопада № 14, поляк, б/п, работал на центральном телеграфе, в прошлом являлся членом организации «ПОВ» и «ОЗН», бывш. жандарм.

228. БЕЛЯВСКАЯ Ядвига Иосифовна, 1914 г. рожд., урож. и жит. г. Дрогобыч, ул. Стрийская № 37, полька, б/п, работала старшей телефонисткой междугородней телефонной станции, состояла членом женской военной организации «Герцеж».

229. ЛАБИНДКОВСКИЙ Мечислав Иосифович, 1905 г. рожд., урож. г. Броды, Львовской обл., прожив. г. Дрогобыч, ул. Снежна № 2, поляк, б/п, работал на центральном телеграфе, поляк, б/п.

Разрабатывались как группа враждебно настроенная против соввласти, проводящая антисоветскую агитацию.

40. Агдело № 82 «Дикообразы»

230. БРАСИЛИТЕН Ушер-Селич Хаимович, 1907 г. рожд., урож. и жит. г. Дрогобыч, ул. Подваля № 9, еврей, б/п, работал переплетчиком типографии, состоял членом сионистской организации.

231. БРАСИЛИТЕН Файвель, 1912 г. рожд., урож. и жит. г. Дрогобыч, ул. Токарская № 4, еврей, член сионистской партии «Нос», работал переплетчиком типографии.

232. БРИНЕ Мойхеш Зайвелевич, 1907 г. рожд., урож и жит. г. Дрогобыч, ул. Мицкевича № 21, еврей, б/п, работал наборщиком типографии, являлся членом сионистской организации.

233. БАКЕНРОБ Максимильян Изакович, 1912 г. рожд., урож. с. Болеховцы, прож. г. Дрогобыч, ул. Горького № 2, еврей, б/п, студент пединститута.

234. ГОТЕСМАН Абрагам, 1913 г. рождения, урож. и жит. г. Дрогобыч, ул. Подваля № 10-а, еврей, б/п, работал бухгалтером Облтопотдела.

235. БЕКЕНДОРФ-ГЕРЦМАН Изак Моисеевич, 29 лет, урож. и жит. г. Дрогобыч, ул. Герцена № 28, еврей, б/п, без опр. занятий, сын мелкого торговца.

236. РУДЕНФЕР Борух, еврей, б/п, работал на заводе в б. Галиции.

Разрабатывались как участники сионистской к-р организации, проводившие активную борьбу против соввластии, компартии.

41. Агдело № 94 «Фалангисты»

237. КИШКО Михаил Григорьевич, 1919 г. рожд., урож. и жит. с. Колпец, Дрогобычской обл., укр., б/п, работал в своем сельском хозяйстве, бывш. участник организации «ОУН».

238. ЯНЕВ Левко Семенович, 1921 г. рождения, урож. и жит. с. Колпец, Дрогобычской обл., укр., б/п, работал в своем сельском хозяйстве, бывш. участник организации «ОУН».

239. ФАРИН Николай Петрович, 1911 г. рожд., укр., б/п, работал в своем сельском хозяйстве, урож. и жит. с. Колпец, бывш. участник организации «ОУН».

240. СИНУТА Игнат Петрович, 1915 г. рожд., урож. и жит. с. Колпец, укр., б/п, работал в своем сельском хозяйстве, бывш. участник организации «ОУН».

241. СИНУТА Иосиф Петрович, 1918 г. рожд., урож. и жит. с. Колпец, укр., б/п, работал в своем сельском хозяйстве, бывш. участник организации «ОУН».

242. КУЛИК Михаил Михайлович, 1915 г. рожд., урож. и жит. с. Колпец, укр., б/п, работал в своем сельском хозяйстве, бывш. участник организации «ОУН». 
243. КУЛИК Василий Михайлович, 1907 г. рожд., урож. и жит. с. Колпец, укр., б/п, работал в своем сельском хозяйстве, бывш. участник организации «ОУН».

244. КУЛИК Михаил Иванович, 1908 г. рожд., урож. и жит. с. Колпец, укр., б/п, работал в своем сельском хозяйстве, бывш. участник организации «ОУН».

245. КЛИМКО Михаил Васильевич, 1915 г. рожд., урож. и жит. с. Колпец, укр., б/п, работал в своем сельском хозяйств., бывш. участник организации «ОУН».

246. АНДРИЕВСКИЙ Василий Иосифович, 1910 г. рожд., урож. и жит. с. Колпец, укр., б/п, работал в своем сельском хозяйстве, бывш. участник организации «ОУН».

247. ПОЛОМАР Иосиф Васильевич, 1910 г. рожд., урож. и жит. с. Колпец, укр., б/п, работал в своем сельском хозяйстве, бывш. участник организации «ОУН».

248. КИШКО Богдан Михайлович, 1919 г. рожд., урож. и жит. с. Колпец, укр., б/п, работал в своем сельском хозяйстве, бывш. участник организации «ОУН».

249. ЯЛОХА Михаил, 1914 г. рожд., урож. с. Колпец, прожив. с. Стебник, Дрогобычского р-на, укр., б/п, работал в своем сельском хозяйстве, бывш. участник организации «ОУН».

250. ВАКЛЮК Стефан Максимович, 1918 г. рожд., урож. и жит. с. Колпец, укр., б/п, работал в своем сельском хозяйстве, бывш. участник организации «ОУН».

251. КУЛИК Михаил Юрьевич, 1914 г. рожд., урож. и жит. с. Колпец, укр., б/п, работал в своем сельском хозяйстве, бывш. участник организации «ОУН».

Разрабатывались по окраске «укр. к-р», лица, проводящие антисоветскую националистическую деятельность.

\section{2. Агдело № 326 «Посредники»}

253. ЧЕРНЫЙ-ГОРОХОВСКИЙ Иван Борисович, 1914 г. рожд. урож. с. Дубрава, Стрийского р-на, прож. в г. Сколе, укр., б/п, работал мастером в пекарне, из рабочих, в прошлом осужден польским судом за украинскую нац. деятельность.

254. ЧОБЫЧ Михалина, 22 лет, урож. и жит.ница с. Любинцы, Сколевского р-на Дрогобычской обл., укр., б/п, работала в сельском хозяйстве отца, состояла членом украинской к-р нац. организации.

255. ПЕТРИКАН Михаил, 30 лет, урож. и жит. с. Стыново-Нижняя, Сколевского p-на, укр., б/п, работал учителем начальной школы, в 1940 г. арестовывался НКВД за переправу оуновцев за кордон.

256. ЦУМАК, 30 лет, урож. с. Стыново, Сколевского р-на, скрывался укр. б/п, без. опр. занятий, являлся членом укр. к-р нац. организации.

Разрабатывались как участники украинской к-р нац. организации и проводящие свою вражескую деятельность, а также занимавшиеся переправой националистов за кордон.

43. Агдело №150 «Мечтатели»

257. ГРЕЧИН Янина Собестьяновна, 1909 г. рожд. полька, работала на заводе № 1, быв. «Галиция» слесарем, член завкома и депутат Горсовета, бывш. проститутка.

258. СВЕНТАНЬ Здислав Густавович, 1920 г. рожд., поляк, работал парикмахером в коммунальной парикмахерской, два брата за рубежом.

Во время пребывания немцев были связаны с офицерами, СВЕНТОНЬ поддерживал связь с агентом «гестапо». Разрабатывались по подозрению в шпионаже. 
44. Агдело № 95 «Закордонники»

259. СЛОНСКИЙ Мирон Максимович, 1921 г. рожд., урож. и жит. с. Трускавец, Дрогобычской обл., ул. Стебницкая №2, укр., б/п, из кулаков, пытался перейти границу в сторону Германии.

260. РЕЗНЯК Славко Александрович, 1920 г. рожд., урож. с. Трускавец, Дрогобычской обл., ул. Жарельня №10, укр., б/п, являлся соучастником организации «ОУН», пытался бежать в Германию.

261. БИСЯК Николай Антонович, 1916 г. рожд., урож. и жит. с. Трускавец, ул. Холодна №7, поляк, работал парикмахерок на курорте, являлся участником укр. нац. организации, пытался бежать в Германию, с целью вступления в украинский легион.

262. БЕЛАС Роман Андреевич, 1918 г. рожд., урож. и жит. с. Трускавец, укр., работал парикмахером на курорте, являлся членом организации «ОУН», пытался бежать в Германию для вступления в украинский национальный легион.

263. БЕЛАС Михайил Андреевич, 1920 г. рожд., урож. и жит. с. Трускавец, укр., б/п, являлся участником «ОУН» пытался перейти границу в сторону Германии, для вступления в укр. нац. легион.

264. РЕЗНЯК Роман Александрович, 1918 г. рожд., урож. и жит. с. Трускавец, ул. Жарельня № 10, укр., б/п, из кулаков, являлся членом укр. к-р нац. организации «ОУН», пытался бежать в Германию, для вступления в укр. нац. легион.

265. ПАВЛЮКОВИЧ Иван Дмитриевич, 1915 г. рожд., укр., б/п, работал парикмахером на курорте в Трускавец, сын крупного богача, активный член организации «ОУН», пытался бежать в Германию для вступления в укр. нац. легион.

266. ПРИСТАЙ Василий Дмитриевич, 1918 г. рожд., урож. и жит. с. Трускавец, укр., б/п, учащийся технической школы, в прошлом член организации «ОУН», пытался перейти границу в сторону Германии для вступления в украинский легион.

267. ВЕРЕТКО Николай Илькович, 1909 г. рожд., урож. и жит. с. Трускавец, ул. Яроша № 4, укр., б/п, работал агентом по торговле на курортах, в прошлом активный член «ОУН», пытался бежать в Германию для вступления в легион.

268. ПАВЛЮКОВИЧ Василий Дмитриевич, 1912 г. рожд., урож. и жит. с. Трускавец, укр., б/п, сын крупного богача, пытался перейти границу в сторону Германии для вступления в украинский легион.

Разрабатывались по подозрению в проведении активной антисоветской нац. деятельности, направленной на отторжение Украины от Советского Союза.

45. Агдело № 302 «Беглецы»

269. ЛАВРОВ-ЛАВРИВ Роман Иванович, 1912 г. рожд. урож. с. Тустановичи, Бориславского р-на, прож. г. Борислав, укр., б/п, без опр. занятий, в прошлом судим за активную оуновскую деятельность.

270. ЛАВРОВ Иван Иванович, 1915 г. рожд., урож. с. Тустановичи, Бориславського p-на, прож. г. Борислав, укр., б/п, работал секретарем завкома 2-го нефтепромысла.

271. ВЕЛЬГУШ Агафья Васильевна, 1913 г. рожд., урож. и жит. г. Дрогобыч, ул. Горишня Брама № 66, укр., б/п, без опр. занятий, бывш. член организации «Сокол».

272. ШЕВЧУК Любов Ивановна, 1919 г. рожд., урож. с. Болеховцы, Дрогобычского p-на, укр., б/п, без опр. занятий, активная националистка, в последнее время выполняла роль связиста краевой экзекутивы «ОУН» г. Львов. 
273. СЕЛЕЦКАЯ Мария Степановна, 1921 г. рожд., урож. и жит. г. Самбор, укр., б/п, без опр. занятий, член организации «ОУН», выполняла роль повитового курьера, два брата, активные оуновцы, бежали за кордон.

274. СТЕБЕЛЬСКАЯ Ирена-Анна Ильинична, 1913 г. рожд., урож. с. Голин, Калушского р-на, Станиславской обл., прожив. г. Самбор, укр., б/п, работала инструктором рай. ОНО, украинская националистка.

275. АНДРИАНОВИЧ Ярослава Юлиановна, 1914 г. рожд., урож. с. Тустановичи, Бориславского р-на, прожив. г. Борислав, укр., б/п, без опр. занятий, дочь попа, брат ее укр. националист, бежал за кордон.

276. ЦМОЦ Константин Григорьевич, 1914 г. рожд., урож. и жит. с. Вижня, Сколевского р-на, Дрогобычской обл., укр., б/п, активный украинский националист, один из руководителей «ОУН».

277. ИЛЬКИВ Николай Михайлович, 1910 г. рожд., урож. с. Тустановичи, Бориславского р-на, Дрогобычской обл., судившийся в 1933 г. за активную оуновскую деятельность.

278. ГНАТОВ Матвей Петрович, 1906 г. рожд., урож. и жит. г. Борислав, член «ОУН», в 1932 г. арестовывался за оуновскую деятельность.

279. ИВАНЧУК Иван Степанович, 1905 г. рожд., урож. и жит. г. Борислав, член «ОУН», з 1932 г. арестовывался за оуновскую деятельность.

280. БАЧИНСКИЙ Ярослав Васильевич, 1914 г. рожд., урож. и жит. г. Борислав, укр., б/п, являлся членом «ОУН», за что арестовывался польскими властями.

Разрабатывались как участники украинской нац. к-р организации «ОУН», проводившие активную повстанческую работу, направленную против Советского Союза.

46. Агдело № 100 «Семейка»

281. СТАЦКАЯ Ядвига Антоновна, 1914 г. рожд., урож. и жит. г. Дрогобыч, ул. Островского № 14, укр., б/п, работала секретарем Облсобеза, родители - быв. владельцы нефтяных вышек.

282. СТАЦКАЯ Стефания Антоновна, 1919 г. рожд., урож. и жит. г. Дрогобыч, ул. Островского № 14, укр., б/п, родители - быв. владельцы нефтяных вышек.

283. СТАЦКАЯ Теодозия Семеновна, 1896 г. рожд., урож. г. Борислав, прож. г. Дрогобыч, ул. Островского № 14, укр., б/п, домохозяйка, быв. владелица нефтяных вышек.

284. ТАРАТУЦКИЙ Владимир Якубович, 1912 г. рожд., урож. г. Борислав, прож. г. Стрий, безпартийный, работал инженером на бумажной фабрике.

285. ТАРАТУЦКАЯ Евстафия Антоновна, 1914 г. рожд., урож. г. Дрогобыч, прож. с. Кохавино, Дрогобычской обл., укр., б/п, родители бывш. владельцы нефтяных вышек.

286. ЧЕРЕВКО Владимир Теодорович, 1913 г. рожд., прож. г. Дрогобыч, ул. Клебанская № 8, укр., б/п, работал экономистом «Укрнефтепреработка», бывш. адвокат.

Разрабатывались как активные украинские националисты, распространявшие провокационные слухи против СССР, группировавшие вокруг себя антисоветский элемент .

47. Агдело № 122 «Мечтатели»

287. КРУГЛЫЙ Теофил Николаевич, 35 лет, урож. г. Дрогобыч, прожив. г. Дрогобыч, ул. Млынки, рабочий завода «Польмин», член украинской «Просвиты». 
288. ПАСИНОВИЧ Филько Дмитриевич, 1908 г. рожд., украинец, урож. и жит. г. Дрогобыч, ул. Раневицкая, укр., б/п, работал на заводе быв. «Польмин», укр. националист.

289. ПАСИНОВИЧ Григорий Дмитриевич, 1907 г. рожд., урож. и жит. г. Дрогобыч, ул. Рановецкого, укр., б/п, работал на заводе быв. «Польмин», укр. националист.

290. ДЕРЕЖИЦКИЙ Василий Григорьевич, 1905 г. рожд., урож. и жит. г. Дрогобыч, ул. Млинарского № 9, укр. б/п, работал на заводе «Польмин», укр. националист.

291. ШИМКО Михаил Григорьевич, 1900 г. рожд., урож. и жит. г. Дрогобыч, ул. Плебанская-Нижняя, укр. б/п, работал на заводе б. «Польмин», укр. националист.

292. ГЕВКО Йосиф Иванович, 52 лет, урож. и жит. г. Дрогобыч, укр., б/п, работал на ж.д. транспорте, являлся руководителем «Просвиты».

293. БРОВАРСКИЙ Рудольф Петрович, 1907 г. рожд., урож. и жит. г. Дрогобыч, ул. Раневицка № 6, укр., б/п, работал охранником на заводе бывш. «Польмин», украинск ий националист.

Разрабатывались, как бывш. члены украинской организации «Просвита», организованно связанные между собой и с заграницей, а также занимавшиеся антисоветской деятельностью.

48. Агдело № 67 «Мелюзга»

294. РАЙНГАРТЕН Герц Изаконич, 1913 г. рожд., урож. и жит. г. Дрогобыч, ул. Райха № 19, еврей, б/п, не работал, из купцов, являлся активным членом фашисткой организации «сионистов-ревизионистов».

295. ТНЕКЕНДОРФ Матес Гаршович, 1912 г. рожд., урож. г. Самбор, прож. г. Дрогобыч, ул. Юра №16, еврей, б/п, бухгалтер Облторготдела, из торговцев, являлся руководителем фашисткой молодежной организации «сионистов-ревизионистов».

296. ФРИДМАН-РАЙХ Жико Озяшевич, 1917 г. рожд., урож. и жит. г. Дрогобыч, ул. Слоный ставок №10, еврей, б/п, работал инструктором «Динамо», из крупных купцов, являлся активным членом организации «сионистов-ревизионистов».

297. БРОХЕР Макс, 1913 г. рожд., урож. и жит. г. Дрогобыч, ул. Стрийская № 102, еврей, б/п, не работал, из торговцев, являлся активным членом организации «сионистов-ревизионистов».

Разрабатывались по окраске «сионисты» как активные члены еврейской фашистской организации фашистов-ревизионистов, занимавшиеся антисоветской деятельностью.

\section{9. Агдело № 151 «Беглецы»}

298. МОСКАЛ Анатолий Станиславович, 39 лет, урож. г. Дрогобыч, поляк, бывш. конфидент польской полиции, бежавший вместе с белополяками за границу, в последнее время находился на нелегальном положении.

299. НЕДОВИЧ Мария Станиславовна, 1913 г. рожд., урож. г. Стравы, Львовской обл., прожив. г. Дрогобыч, родные проживают на территории Германии, полька, работала маникюршей в парикмахерской.

300. НЕДОВИЧ Михаил Янович, 1910 г. рожд., урож. г. Добромыль, прожив. г. Дрогобыч, поляк, работал на почте.

301. КУШНИР Теофил Теодорович, 1907 г. рожд., урож и жит. г. Дрогобыч, поляк, б/п, работал почтальоном на почте. 
Фигурант дела МОСКАЛ Антоний переброшен гестапо для шпионской работы на территории СССР, о чем осведомлены остальные фигуранты. Разрабатывается как подозревавшие в шпионаже в пользу Германии.

50. Агдело № 110 «Недовольные»

302. КОБРИН Юзеф Коралевич, 1902 г. рожд., урож. и жит. г. Дрогобыч, ул. Словацкого, поляк, быв. член ППС, бывш. конфидент польской полиции, работал на заводе № 1 .

303. ГАЛУШКО Мечеслав Антонович, 1912 г. рожд., урож. и жит. г. Дрогобыч, ул. Словатского, поляк, без опр. занятий.

304. САВЧЕНКО Григорий Григорьевич, 1917 г. рожд., урож. г. Фрунзе, ур. чл. ВЛКСМ, красноармеец, шофер военной прокуратуры 8 корпуса, в Красной Армии состоит с 1938 г.

Разрабативались по подозрению в проведении шпионской деятельности.

51. Агдело № 217 «Блок»

305. КАШУБА Нестор Михайлович, 1906 г. рожд., урож. и жит. г. Дрогобыч, ул. Охронек № 3, укр., б/п, работал в Горплане Горсовета.

КАШУБА Роман Михайлович, 1915 г. рожд., урож. и жит. г. Дрогобыч, ул. Бична Охронек № 32, укр., б/п, работал в домоуправлении, при польвластях был секретарем тюрьмы.

Разрабатывались как украинские националисты, проводившие нелегальные сборища, и группировали вокруг себя антисоветский элемент.

\section{4. Агдело № 413 «Округ»}

307. ГАБШИЙ Роман Михайлович, 1923 г. рожд., урож. и жит. с. Трускавец Дрогобычского р-на, укр., б/п, учащийся 8 класса средней школы, являлся участником к-р организации украинских националистов «ОУН».

308. ЛИСОВИЧ Наталья Иванова, 1924 г. рожд., урож. с. Далява, прожив. г. Дрогобыч, ул. Стрыйская № 187, укр., б/п, учащаяся школы, являлась участницей антисоветской оуновской организации.

309. ПЕТРИК Анна Степановна, 1925 г. рожд., урож. и прожив. г. Дрогобыч, ул. ВерхняКолиева № 10, укр., б/п, учащаяся 8 класса средней школы, член организации «ОУН»,

310. ЛЕМЕХ Ирина Ильковна, 1923 г. рожд., урож. и прожив г. Дрогобыч, ул. Зализна № 47, укр., б/п, учащаяся 9 класса средней школы, являлась участницей оуновской организации.

311. КУЛИНИЧ Степан Тимофеевич, 1923 г. урож. и жит. г. Дрогобыч, ул. Газова № 2, укр., б/п, студент пединститута, являлся участником организации «ОУН».

312. ПЕТРИВ Славко Иосифович, 1921 г. рожд., урож. с. Трускавец, прожив. г. Дрогобыч, укр., б/п, учащийся школы.

313. РИЗНЯК Мирослав Алексеевич, 1923 г. рожд., урож. и жит. с. Трускавец, укр., б/п, студент пединститута, являлся участником а/с организации «ОУН».

314. АНТОНИВ Ярослав Михайлович, 1922 г. рожд., урож., с. Стебник, прожив. г. Дрогобыч, укр., б/п, студент пединститута, является членом оуновской организации,

315. ТАТАРСКИЙ Евгений Иосифович, 1921 г. рожд., урож. и жит. г. Дрогобыч, ул. Ивана Франко № 44, укр., б/п, студент пединститута, являлся участником оуновской организации. 
316. КУЙДИЧ Иван Юрьевич, 1923 г. рожд., урож. и жит. г. Дрогобыч, ул. Листопада № 53, укр., б/п, учащийся школы, являлся участником оуновской организации.

317. ЛОБОДА Ольга Васильевна, 1921 г. рожд., урож. с. Модричи, Дрогобычской обл, прожив. г. Дрогобыч, укр. б/п, учащаяся школы, являлась участником оуновской организации,

318. ПРИМАК Ольга Григорьевна, урож. с. Модрычи, Дрогобычской обл., прожив. г. Дрогобыч, укр., б/п, учащаяся школы.

319. ИВАСИКИВ Ольга Ивановна, 1924 г. рожд., урож. и жит.ница г. Дрогобыч, ул. Ивана Франка № 52, укр., б/п, учащаяся школы, являлась участницей организации «ОУН».

320. СПАНЧАК Иван Онуфриевич, 1923 г. рожд., прожив. г. Дрогобыч укр., б/п, учащийся 9 класса средней школы, являлся участником антисоветской оуновской организации.

321. БОЖИК Николай Михайлович, 1922 г. рождения, жит. г. Дрогобыч, ул. 17 вересня № 67, укр., б/п, учащийся 10 школы, являлся участником оуновской организации.

322. КРИШТАЛЬ Теодор Иванович, 1923 г. рождения, урож. с. Гаи Ныжни, Дрогобычской обл., проживал г. Дрогобыч, укр., б/п, учащийся 8 класса средней школы, являлся участником организации «ОУН».

323. ФАРИМАН Мирослав Олексович, 1924 г. рожд., урож. с. Доброгостыв, Стебник, прожив. с. Доброгостыв, укр. б/п, учащийся школы, являлся участником оуновской организации,

324. ТАТАРСКИЙ Осип Васильевич, 1922 г. рожд., урож. и жит. г. Дрогобыч, ул. Стрийская № 103, укр., б/п, студент пединститута, являлся участником оуновской организации,

325. КРАВЕЦ Иван Васильевич, 1924 г. рожд., урож. с. Гаи Ныжни Дрогобычской обл., прожив. г. Дрогобыч, укр., б/п, учащийся 9 класса средней школы, являлся участником оуновской организации.

326. ДЕЛЕНКО Богдан Витович, 1923 г. рожд., урож. с. Довге Добривляны, прожив. г. Дрогобыч, ул. Пушкина № 24, укр., б/п, учащийся школы, являлся участником ОУН-овской организации.

327. ВИШКО Юлий Петрович, 1920 г. рожд., урож. и жит. г. Борислав, укр., б/п, учащийся школы, являлся участником ОУН-онвской организации.

328. ЖГУТ Андрей Степанович, 1922 г. рожд., урож. с. Воля Якубова, прожив. г. Дрогобыч, укр., б/п, учащийся 9 класса средней школы, являлся участником ОУН-овской организации.

329. СКРИПУХ Иван Илькович, 1922 г. рожд., урож. и жит. г. Дрогобыч, ул. Снежна № 33, укр., б/п, учащийся 10 класса средней школы, являлся участником ОУН-овской организации.

330. ФЕДУШ Владимир Иванович, 1922 г. рожд., урож. с. Ластивка, прожив г. Дрогобыч, укр., б/п, учащийся 8 класса средней школы, являлся участником ОУН-овской оранизации.

331. КУНЦИВ Владимир Степанович, 1923 г. рожд., урож. и жит. с. Попели Дрогобычского р-на, укр., б/п, учащийся 8 класса средней школы, являлся участником ОУН-овской организации.

332. МОТЫКА Иванна Васильевна, 1924 г. рожд., урож. и жит. с. Трускавец, ул. Холодная № 12, укр., б/п, учащаяся, являлась участницей ОУН-овской организации. 
333. ЯВОРСКИЙ Василий Михайлович, 1922 г. рожд., урож. и жит. г. Борислав, ул. Ситники № 3, укр., б/п, иждивенец, являлся участником ОУН-овской организации.

334. ПИЛИПЧАК Михаил Владимирович, 1923 г. рожд., урож. и жит. г. Борислав, ул. Коцюбинского № 46, укр., б/п, работал на нефтепромысле чернорабочим, являлся участником ОУН-овской организации,

335. БАЧИНСКИЙ Петр Сеневич, 1918 г. рожд., урож. и жит. с. Тустановичи, Дрогобычского р-на, укр., б/п, работал на нефтепромысле, являлся участником ОУНовской организации.

336. ПИЛЬКО Роман Теодорович, 1921 г. рожд., урож. и жит. с. Тустановичи, Дрогобычского р-на, укр, б/п, работал в своем сельском хозяйстве, являлся участником ОУН-овской организации.

337. ЗАРИЦКИЙ Дмитрий Васильевич, 1921 г. рожд., урож. и жит. села Тустановичи, Дрогобычского р-на, ул. Франко № 9, укр., б/п, без опр. занятий, являлся участником ОУН-овской организации.

338. ГУТОВИЧ Богдан Антонович, 1922 г. рожд., урож. и жит. г. Дрогобыч, укр., б/п, учащийся школы № 1, являлся участником ОУНовской организации,

339. БРАТУСЬ Василий Михайлович, 1922 г. рожд., урож. и жит. с. Унятычи Дрогобычского р-на, укр., б/п, учащийся, являлся участником ОУН-овской организации. 340. БЕРЕЖНИЦКАЯ Мария Алексеевна, 1921 г. рожд., урож. с. Черехава, Самборского р-на, проживала в г. Самбор, ул. Замейская № 34, укр., б/п, учащаяся средней школы, являлась участницей ОУН-овской организации.

341. ВОЛОШИН Василий Дмитриевич, 1922 г. рожд., урож. и жит. с. Вишня, Дрогобычской обл., укр., б/п, учащийся школы, являлся участником ОУН-овской организации.

342. ГРАБОВСКАЯ Татьяна Марковна, 1920 г. рожд., урож. и жит. Самбор, ул. Замейская № 21, укр., б/п, учащаяся средней школы, являлась участницей ОУНовской организации.

343. ГОРНИЦКИЙ Ростислав Зенонович, 1923 г. рожд., урож. и жит. г. Самбор, ул. Коперника № 21, укр. б/п, учащийся средней школы,

344. ФЛЮНТ Тарас Зенонович, 1921 г. рожд., урож. и жит. г. Самбор, ул. Змиевская № 17, укр., б/п, учащийся в средней школе, являлся участником ОУН-овской организации. 345. ФИЛЦ Роман Михайлович, 1922 г. рожд., урож. и жит. г. Самбор, ул. Церковная № 4, укр., б/п, учащийся школы, являлся участником ОУН-овской организации.

346. ПЛОШКЕВИЧ Ирина Юлиановна, 1923 г. рожд., урож. и жит. г. Самбора, укр., б/п, учащаяся школы, являлась участницей ОУН-овской организации.

347. КУЦАН Богдан Иванович, 1920 г. рожд., урож. и жит. г. Самбор, ул. Замейская № 67, укр., б/п, учащийся 10 класса средней школы, являлся участником ОУН-овской организации.

348. ХОМЯК Илько Григорьевич, 1920 г. рожд., урож. и жит. с. Унятичи, Дрогобычского р-на, укр., б/п, являлся участником ОУН-овской организации.

349. ХОМЯК Кароль Мариевич, 1921 г. рожд., урож. и жит. с. Унятичи, Дрогобычского p-на, укр., б/п, являлся участником ОУН-овской организации.

350. ТОРСКИЙ Андрей Илькович, 1921 г. рожд., урож. и жит. с. Унятичи, Дрогобычского р-на, укр., б/п, являлся участником ОУН-овской организации.

351. ЗАХОРЯК Василий Николаевич, 1920 г. рожд., урож. и жит. с. Лишня, Дрогобычской обл., украинец, б/п, являлся участником ОУН-овской организации. 
352. ДИДУХ Николяй Васильевич, 1921 г. рожд., урож. и жит. села Лишня, украинец, б/п, являлся участником ОУН-овской организации.

353. КОВАЛЬ Петр Степанович, 1921 г. рожд., урож. и жит, с. Медвежа, Дрогобычской обл., укр., б/п, являлся участником ОУН-овской организации.

354. ТЕРЛЕЦКИЙ Иван Николаевич, 1921 г. рожд., урож. и жит. с. Медвежа, Дрогобычской обл., укр., б/п, являлся участником ОУН-овской организации.

355. ЛЬСИК Владимир Михайлович, 1921 г. рожд., урож. и жит. с. Попели, Дрогобычской обл., укр., б/п, являлся участником ОУН-овской организации.

356. ВЫСЕК Владимир Антонович, 1921 г. рожд., урож. с. Попели, Дрогобычской обл., укр., б/п, работал в своем сельском хозяйстве, являлся участником ОУН-овской организации,

357. СТЕЛЬМАХ Ярослав Илькович, 1922 г. рожд., урож. и жит. с. Попели, укр., б/п, работал в своем сельском хозяйстве, являлся участником ОУН-овской организации.

358. КРАМАРЬ Дорка Иосифовна, 1921 г. рожд., урож. и жит. с. Трускавец, укр., б/п, учащаяся неполной средней школы, являлась участницей ОУН-овской организации.

359. ЧАЙКОВСКИЙ Николай Васильевич, 1922 г. рожд., урож. с. Луки, Дублянского p-на, прожив. г. Самбор, ул. Замейская № 9, украинец, б/п, учащийся школы, являлясь участником а/с организации.

360. БАРАНИК Микола Васильевич, 1924 г. рожд., урож. с. Лютовиска, СтароСамборского р-на, прожив. в г. Самбор, Церковная площ. № 8, украинец, б/п, учащийся школы, являлся участником ОУН-овской организации.

361. ХАНАС Антип Васильевич, 1924 г. рождения, урож. с. Берестины, СтароСамборского р-на, прожив. г. Самбор, ул. Цегольна 9 кв., украинец, б/п, учащийся школы, являлся участником ОУН-овской организации.

362. ФЕДИК Владимир Михайлович, 1923 г. рождения, урож. м. Озымина, Дубинского р-на, прожив. г. Самбор, ул. Замейская № 28, украинец, б/п, учащийся школы, являлся участником ОУН-овской организации.

363. ДАНИЛИШИН Андрей Николаевич, 1919 г. рожд., урож. и жит. с. Трускавец, укр., б/п, работал в своем сельском хозяйстве, являлся участником ОУН-овской организации.

364. КОЦЮБА Роман Федорович, 1921 г. рожд., урож. и жит. г. Дрогобыч, ул. Плебания № 8, укр., б/п, работал контролером ЦОК, являлся участником ОУНовской организации.

365. СПРИС Орест Александрович, 1923 г. рожд., урож. и жит. с. Тустановичи, ул. И. Франко № 21, укр., б/п, учащийся Бориславской школы, являлся участником ОУНовской организации.

366. ОМРОЗИЙ Яким Дмитриевич, 1911 г. рожд., урож. с. Чуква, Самборского p-на, находился на нелегальном положении, укр., б/п, являлся участником ОУН-овской организации.

367. ОПРИШКО Корнеля Васильевна, 1921 г. рожд., урож. и жит. с. Тустановичи, укр., б/п, учащаяся Бориславской школы, являлась участницей ОУН-овской организации.

368. КИСИЛИЧНИК Михаил Николаевич, 1922 г. рожд., урож. и жит. с. Трускавец, укр., б/п, работал в своем сельском хозяйстве, являлся участником ОУН-овской организации.

369. ВИТВИЦКИЙ Ярослав Васильевич, 1922 г. рожд., урож. и жит. с. Тустановичи, укр., б/п, учащийся Бориславской школы, являлся участником ОУН-овской организации. 
370. БОЖИК Роман Прокофьевич, 1922 г. рожд., урож. и жит. с. Трускавец, укр., б/п, занимался сельским хозяйством, являлся участником ОУН-овской организации.

371. МОРОЗ Дмитрий Дмитриевич, 1922 г. рожд., урож. и жит. с. Стебник, Дрогобычской обл., укр., б/п, занимался сельским хозяйством, подозревался в причастности к организации «ОУН».

372. МОРОЗ Михаил Юркович, 1923 г. рожд., урож. и жит. с. Стебник, укр., б/п, находился на иждивении родителей, подозревался в причастности к организации «ОУН».

373. БИЛАС Николай Константинович, 1919 г. рожд., урож. и жит. с. Модричи, Дрогобычской обл., укр., б/п, занимался сельским хозяйством, подозревался в причастности к ОУН-овской организации.

374. МАГУР Николай Михайлович, 1921 г. рожд., урож. и жит. с. Модричи, укр., б/п, занимался сельским хозяйством, являлся участником ОУН-овской организации.

375. ХЕВПА Николай Михайлович, 1922 г. рожд., урож. и жит. с. Модричи, укр., б/п, занимался сельским хозяйством, подозревался в причастности к организации «ОУН».

376. КОВЦУН Богдан, 1921 г. рожд., урож. и жит. с. Модричи, укр., б/п, занимался сельским хозяйством, подозревался в причастности к организации «ОУН».

377. ЖИГОЛЯК Михаил Юркович, 1921 г. рожд., урож. и жит. с. Станеля, Дрогобычской обл., укр., б/п, занимался сельским хозяйством, подозревался в причастности к ОУН-овской организации.

378. СТЕЦКЕВИЧ Ярослав Михайлович, 1922 г. рожд., урож. и жит. села Колпец, Дрогобычской обл., укр. б/п, работал в вагонном депо ст. Дрогобыч, являлся участником ОУН-овской организации.

379. ГОДОВАНЕЦ Михаил, 1919 г. рожд., урож. и жит. с. Модричи, Дрогобычской обл., укр., б/п, занимался сельским хозяйством, подозревался в причастии к ОУН-овской организации,

380. КУЛЬЧИЦКИЙ Игорь Теодорович, 1920 г. рожд., урож. и жит. с. Кульчицы, Дрогобычской обл., укр., б/п, учащийся, подозревался в причастности к организации «ОУН».

381. ЛУЖЕЦКИЙ Осип Якубович, 1922 г. рожд., урож. и жит. с. Ступница, Дрогобычской обл., Дублянского р-на, укр., б/п, находился на иждивении родителей, подозревался в причастности к ОУН-овской организации.

382. НОВОСЕЛЬСКИЙ Зиновий Петрович, 1922 г. рожд., урож. и жит. Кружики, Дублянского р-на Дрогобычской обл., укр., б/п, находился на иждивении родителей, подозревался в причастии к ОУН-овской организации.

383. ОПРИШКО Евгения Катериновна, 1923 г. рожд., урож. г. Перемышль, прож. г. Дрогобыч, ул. Франко № 40, укр., б/п, студентка педкурсов, подозревалась в причастности к ОУН-овской организации.

384. ПРИСТАЙ Мирослав Андреевич, 1923 г. рожд., урож. и жит. с. Трускавец, ул. Суховолья № 53, укр., б/п, работал слесарем в техникуме, подозревался в причастности к организации «ОУН».

385. ПРИСТАЙ Василий Андреевич, 1922 г. рожд., урож. и жит. с. Трускавец, ул. Суховолья № 53, укр., б/п, студент техникума, подозревался в причастности к организации «ОУН».

386. ТЕРЛЕЦКИЙ Зенон Григорьевич, 1923 г. рожд., урож. и жит. с. Тустановичи, Бориславского р-на, ул. Коцюбинского № 66, укр., б/п, учащийся школы, подозревался в причастности к ОУН-овской организации. 
387. АДРЯНОВИЧ Орест Ильянович, 1923 г. рожд., урож. и жит. с. Тустановичи, ул. Франко № 1, укр., б/п, учащийся школы, подозревался в причастности к организации «ОУН».

388. ПАПИШ Ярослав Михайлович, 1922 г. рожд., урож. с. Рудки, Рудковского p-на, прожив. г. Самбор, укр., б/п, учащийся школы, являлся участником ОУН-овской организации.

389. КУЛЬЧИЦКИЙ Марьян Дмитрович, 1923 г. рожд., урож. с. Береги, Самборского p-на, прожив. с. Тустановичи, Бориславского р-на, ул. Коцюбинского № 27, укр., б/п, учащийся школы, подозревался в причастности к ОУН-овской организации.

Разрабатывались, как участники контрреволюционной организации украинских националистов, проводившие активную антисоветскую деятельность, подготавливая вооруженное восстание.

\section{Джерело:}

Галузевий державний архів Служби безпеки Украӥни. Ф. 71. Оп. 6. Спр. 9. Арк. 1-37.

\section{BIBLIOGRAPHY}

Білас, 1994 - Білас І. Репресивно-каральна система в Україні 1917 - 1953. Суспільно-політичний та історико-правовий аналіз. У двох книгах. К.: Либідь; Військо України, 1994. Кн. 1. 432 с.

Ільюшин, 2003 - Ільюшин І. Польське підпілля на території Західної України в роки Другої світової війни. Незалежний культурологічний часопис «ї» [гол. ред. Т. Возняк]. Львів, 2003. С. 152-171.

Ільюшин, 2001 - Ільюшин І. Протистояння УПА і АК (Армії Крайової) в роки Другої світової війни на тлі діяльності польського підпілля в Західній Україні. К.: Інститут історії України НАН України, 2001. 289 с.

Ільюшин, 2009 - Ільюшин I. Українська повстанська армія і Армія Крайова. Протистояння в Західній Україні (1939 - 1945 рр.). К.: Вид.дім «Києво-Могилянська академія», 2009. 399 с.

Кентій, 1999 - Кентій А. Нарис боротьби ОУН-УПА в Україні (1946 - 1956 рр.). К.: Інститут історії України НАН України, 1999. 111 с.

Киричук, 2003 - Киричук Ю. Український національний рух 40 - 50-х років ХХ століття: ідеологія та практика. Львів: Добра справа, 2003. 464 с.

Кондратюк, Кондратюк 2000 - Кондратюк К., Кондратюк С. Репресії органів НКВС проти населення західних областей України $(1939$ - 1941) // Наукові зошити історичного факультету. Львів, 2000. Вип. 3. С. 146-149.

Кондратюк, Кондратюк 2001 - Кондратюк К., Кондратюк С. Становлення і характер радянської влади в Західній Україні (вересень 1939 - червень 1941 рр.) // Галичина. 2001. № 5-6. С. 347-353.

Литвин, Луцький, Науменко, 1999 - Литвин М. Р., Луцький О. І., Науменко К. Є. 1939: Західні землі України. Львів: Інститут українознавства ім. І. Крип’якевича НАН України, 1999. 152 с.

Луцький, 1996 - Луцький О. «Радянізація» Львов: вересень 1939 - червень 1941 // Львів. Історичні нариси. Львів, 1996. С. 448-450.

Макарчук, 2004 - Макарчук С. Радянські методи боротьби з ОУН і УПА. 1944 - 1945 pp. // Українська Повстанська Армія у боротьбі проти тоталітарних режимів. Львів, 2004. С. 210 - 223.

Нікольський, 2003 - Нікольський В. М. Репресивна діяльність органів державної безпеки СРСР в Україні (кінець 1920 - 1950 рр.): Історико-статистичне дослідження. Донецьк, 2003. $623 \mathrm{c}$.

ОУН і УПА, 2005 - Організація Українських Націоналістів і Українська Повстанська Армія. Історичні нариси / [за ред. С. Кульчицького]. К.: Інститут історії України НАН України, 2005. $496 \mathrm{c}$.

Патриляк, 2012 - Патриляк І. «Встань і борись! Слухай і вір...»: українське націоналістичне підпілля та повстанський рух (1939 - 1960 рр.): монографія Іван Патриляк. Львів: Часопис, 2012. $592 \mathrm{c}$. 
Русначенко, 2002 - Русначенко А. Народ збурений: Національно-визвольний рух в Україні й національні рухи опору в Білорусії, Литві, Латвії, Естонії у 1940 - 50-х роках. К.: Університетське видавництво «Пульсари», 2002. 519 с.

Сергійчук, 2005 - Сергійчук В. Український здвиг: Прикарпаття. 1939 - 1955 рр. К.: Українська Видавнича Спілка, 2005. 840 с.

Шаповал, 2001 - Шаповал Ю. Війна після війни // Літопис УПА. Нова серія. Т. 3. Боротьба проти УПА і націоналістичного підпілля: директивні документи ЦК Компартії України. 1943 1959. Київ; Торонто, 2001. 670 с.

Ярош, 1999 - Ярош Б. О. Сторінки політичної історії західноукраїнських земель (30 50-ті рр. ХХ ст.). Луцьк, 1999. 181 с.

\section{REFERENCES}

Bilas, 1994 - Bilas I. Represyvno-karalna systema v Ukraini 1917 - 1953 [The repressive system in Ukraine in 1917 - 1953]. Suspilno-politychnyi ta istoryko-pravovyi analiz. U dvokh knyhakh. K.: Lybid; Viisko Ukrainy, 1994. Kn. 1. 432 pp. [in Ukrainian]

Iliushyn, 2003 - Iliushyn I. Polske pidpillia na terytorii Zakhidnoi Ukrainy v roky Druhoi svitovoi viiny [The Polish underground in the territory of Western Ukraine during the Second World War]. Nezalezhnyi kulturolohichnyi chasopys «I» [hol. red. T. Vozniak]. Lviv, 2003. Pp. 152-171. [in Ukrainian]

Iliushyn, 2001 - Iliushyn I. Protystoiannia UPA i AK (Armii Kraiovoi) v roky Druhoi svitovoi viiny na tli diialnosti polskoho pidpillia $\mathrm{v}$ Zakhidnii Ukraini [The opposition of the UPA and AK (Armija Krajowa) diring the Second World War against the background of the Polish underground's activity in Western Ukraine]. K.: Instytut istorii Ukrainy NAN Ukrainy, 2001. 289 p. [in Ukrainian]

Iliushyn, 2009 - Iliushyn I. Ukrainska povstanska armiia i Armiia Kraiova. Protystoiannia v Zakhidnii Ukraini (1939 - 1945 rr.) [The Ukrainian insurgent army and Armija Krajowa. The opposition in Western Ukraine $(1939$ - 1945)]. K.: Vyd.dim «Kyievo-Mohylianska akademiia», 2009. 399 p. [in Ukrainian]

Kentii, 1999 - Kentii A. Narys borotby OUN-UPA v Ukraini (1946-1956 rr.) [On functioning of UPA departments in Chernivtsi land; An outline of the struggle of OUN-UPA in Ukraine (19461956)]. Kyiv, Instytut istorii Ukrainy NAN Ukrainy, 1999. 111 p. [in Ukrainian]

Kyrychuk, 2003 - Kyrychuk Yu. Ukrainskyi natsionalnyi rukh 40-50-kh rokiv XX stolittia: ideolohiia ta praktyka [Ukrainian Nationalist Movement of 1940s-1950s: Ideology and Practice]. Lviv, Dobra sprava, 2003. 464 p. [in Ukrainian]

Kondratiuk, Kondratiuk 2000 - Kondratiuk K., Kondratiuk S. Represii orhaniv NKVS proty naselennia zakhidnykh oblastei Ukrainy $(1939$ - 1941) [The NKVD Organs' Repressions of the Population of the Western Areas of Ukraine $(1939$ - 1941)] // Naukovi zoshyty istorychnoho fakultetu. Lviv, 2000. Vyp. 3. Pp. 146-149. [in Ukrainian]

Kondratiuk, Kondratiuk 2001 - Kondratiuk K., Kondratiuk S. Stanovlennia i kharakter radianskoi vlady v Zakhidnii Ukraini (veresen 1939 - cherven 1941 rr.) [The Establishment and Character of the Soviet Power in Western Ukraine (September, 1939 - June, 1941)] // Halychyna. 2001. № 5-6. Pp. 347-353. [in Ukrainian]

Lytvyn, Lutskyi, Naumenko, 1999 - Lytvyn M. R., Lutskyi O. I., Naumenko K. Ye. 1939: Zakhidni zemli Ukrainy [1939: Ukraine's Western Lands]. Lviv: Instytut ukrainoznavstva im. I. Krypiakevycha NAN Ukrainy, 1999. 152 c. [in Ukrainian]

Lutskyi, 1996 -Lutskyi O. «Radianizatsiia» Lvova: veresen 1939 - cherven 1941 [«The Sovietization» of Lviv: September, 1939 - June, 1941] // Lviv. Istorychni narysy. Lviv, 1996. Pp. 448-450. [in Ukrainian]

Makarchuk, 2004 - Makarchuk S. Radianski metody borotby z OUN i UPA. 1944 - 1945 rr. [Soviet methods of struggle against OUN and UPA. 1944 - 1945] // Ukrainska Povstanska Armiia u borotbi proty totalitarnykh rezhymiv. Lviv, 2004. Pp. 210-223. [in Ukrainian]

Nikolskyi, 2003 - Nikolskyi V. M. Represyvna diialnist orhaniv derzhavnoi bezpeky SRSR v Ukraini (kinets 1920 - 1950 rr.): Istoryko-statystychne doslidzhennia [The Repressive Activity of the USSR's State Security Agencies in Ukraine (the end of the 1920s - 1950s)]. Donetsk, 2003. 623 p. [in Ukrainian] 
OUN i UPA, 2005 - Orhanizatsiia Ukrainskykh Natsionalistiv i Ukrainska Povstanska Armiia. Istorychni narysy [The Organization of Ukrainian Nationalists and the Ukrainian Insurgent Army] / [za red. S. Kulchytskoho]. - K.: Instytut istorii Ukrainy NAN Ukrainy, 2005. 496 p. [in Ukrainian]

Patryliak, 2012 - Patryliak I. «Vstan i borys! Slukhai i vir...»: ukrainske natsionalistychne pidpillia ta povstanskyi rukh (1939 - 1960 rr.) ["Stand up and fight! Listen and believe...": the Ukrainian nationalist underground and insurgent movement (1939-1960)]. Lviv: Chasopys, 2012. 592 p. [in Ukrainian]

Rusnachenko, 2002 - Rusnachenko A. Narod zburenyi: Natsionalno-vyzvolnyi rukh v Ukraini y natsionalni rukhy oporu v Bilorusii, Lytvi, Latvii, Estonii u 1940 - 50-kh rokakh [The Revolted People: National liberation movement in Ukraine and national resistance movements in Belarus', Lithuania, Latvia, and Estonia in the 1940s - 1950s]. Kyiv, Universytetske vydavnytstvo «Pulsary», 2002. 519 p. [in Ukrainian]

Serhiichuk, 2005 - Serhiichuk V. Ukrainskyi zdvyh: Prykarpattia [the Ukrainian revolt: SubCarpathia]. 1939 - 1955 rr. - K.: Ukrainska Vydavnycha Spilka, 2005. 840 p. [in Ukrainian]

Shapoval, 2001 - Shapoval Yu. Viina pislia viiny [A War after the war] // Litopys UPA. Nova seriia. T. 3. Borotba proty UPA i natsionalistychnoho pidpillia: dyrektyvni dokumenty TsK Kompartii Ukrainy. 1943 - 1959. Kyiv; Toronto, 2001. 670 p. [in Ukrainian]

Yarosh, 1999 - Yarosh B. O. Storinky politychnoi istorii zakhidnoukrainskykh zemel (30 - 50-ti rr. XX st.) [Pages of Political History of the West Ukrainian Lands (1930s -1950s)]. Lutsk, 1999. 181 p. [in Ukrainian]

Стаття надійшла до редакиії 19.04.2018 p. 